\title{
Extraction of protein concentrate from red bean (Phaseolus vulgaris L.): antioxidant activity and inhibition of lipid peroxidation
}

Lucrecia Piñuel ${ }^{1}$, Edgar Vilcacundo², Patricia Boeri ${ }^{1}$, Daniel Alejandro Barrio ${ }^{1}$, Dayana Morales ${ }^{3}$, Adelita Pinto ${ }^{4}$, Roberto Moran, Ivan Samaniego ${ }^{5}$, Wilman Carrillo ${ }^{4 *}$

${ }^{1}$ Universidad Nacional de Río Negro (UNRN-CONICET), Viedma-Argentina.

${ }^{2}$ Department of Research. Bolivar State University. Guaranda-Ecuador

${ }^{3}$ Faculty of Science and Engineering in Food and Biotechnology, Technical University of Ambato. Ambato-Ecuador.

${ }^{4}$ Department of Research. Technical University of Babahoyo, Babahoyo-Ecuador.

${ }^{5}$ Department of Nutrition and Quality. National Institute of Agricultural Research (INIAP), Mejía-Ecuador.

\section{ARTICLE INFO}

Received on: 27/03/2019

Accepted on: 21/05/2019

Available online: 01/09/2019

\section{Key words:}

Common bean, Phaseolus vulgaris, protein concentrate, antioxidant activity, zebrafish larvae.

\begin{abstract}
Red Bean Protein Concentrate (RBPC) and their hydrolysates were used to evaluate the antioxidant capacity. The RBPC protein content was in the range of $57.38 \%-72.68 \%$ of the total sample content. RBPC protein profile showed a range of 15-100 kDa. Phaseolin protein was identified with bands of 45 and $50 \mathrm{kDa}$. Phaseolin protein was found in all the RBPC samples at the different $\mathrm{pHs}$ assayed. In the gastric digestion phase, bands from 60 to $100 \mathrm{kDa}$ were totally hydrolyzed with pepsin. Phaseolin protein $(45$ and $50 \mathrm{kDa}$ ) presented resistance to gastric hydrolysis. All the RBPCs and gastrointestinal digest presented antioxidant activity using ferric-reducing antioxidant power (FRAP), 2,2-azinobis (3-ethyl-benzothiazoline-6-sulfonic acid) (ABTS), oxygen radical absorbance capacity (ORAC), and thiobarbituric acid reactive substances using the in vitro and in vivo methods. RBPC at $\mathrm{pH} 7.0$ presented a value of $95.80 \mu \mathrm{moL}$ TE/g of RBPC (FRAP); $257.12 \mu \mathrm{moL}$ TE/g of RBPC (ABTS), and $1960 \mu \mathrm{moL}$ TE/g of RBPC (ORAC). Duodenal digest of RBPC presented high antioxidant activity with $225.77 \mu \mathrm{moL}$ TE/g of digest (FRAP); $345.21 \mu \mathrm{moL}$ $\mathrm{TE} / \mathrm{g}$ of digest (ABTS); and $3256 \mu \mathrm{moL} \mathrm{TE} / \mathrm{g}$ of digest (ORAC). Gastric and duodenal digest of RBPC were used to inhibit lipid peroxidation using the in vitro method presenting a value of $87.95 \%$ and $93.0 \%$, respectively. When the in vivo method in zebrafish larvae was used, values were $79.03 \%$ and $86.76 \%$, respectively. RBPCs showed no reactive oxygen species (ROS) inhibition. However, RBPCs with gastric and gastrointestinal digests, presented ROS inhibition, $75.30 \%$ for gastric digests and $66.40 \%$ for gastrointestinal digests.
\end{abstract}

\section{INTRODUCTION}

Legumes are important in the human nutrition for their bio components, such as proteins, carbohydrates, fiber, minerals, and lipids. Legumes proteins have a high percentage of lysin amino acids and can complement the proteins from cereals which are deficient in lysin amino acids. In human nutrition, different beans are used for their high nutritional and biological properties. We can mention the beans, such as Phaseolus vulgaris, Cajanus cajan, Lens culinaris, Pisum sativum, and Cicer arietinum,

*Corresponding Author

Wilman Carrillo. Department of Research, Technical University of Babahoyo,Babahoyo-Ecuador.E-mail:wcarrillo@utb.edu.ec which are the important source of protein in the under-developed countries (Achouri and Boye, 2013; Achouri et al., 2012; Boye et al., 2010; Carbonaro et al., 2015; Foschia, 2016; Tosh and Yada, 2010). Legumes proteins can be used in the production of Protein Concentrates (PC) and Protein Isolates (PI). Proteins used in the food industry can be of animal or vegetal origin (e.g., milk and eggs proteins, soybean, lupines, quinoa, amaranth, and bean proteins) (Rodríguez Saint Jean et al., 2013; Boye et al., 2016; Toapanta et al., 2016; Acosta et al., 2016; Vilcacundo et al., 2018a; Carrillo et al., 2017b).

The oxidative stress is defined as a disequilibrium in the production of harmful substances in the organism and the production of antioxidant substances. The oxidative stress is recognized as an important cause of a variety of degenerative diseases, such as Parkinson disease and arthritis. Common free 
radicals produced in the body are oxygen based and termed as reactive oxygen substances. They include different radicals, such as superoxide, hydroxyl, and peroxyl. Many exogenous molecules, that the body requires, help to keep the redox balance and include ascorbic acid, tocopherols, tocotrienols, polyphenols, carotenoids, proteins, and peptides. These components are abundantly found in fruits, vegetables, and legumes. In the past years, food proteins and peptides have been a research subject for their antioxidant activity and the evaluation of ROS inhibition (Carrillo et al., 2017a; Galadari et al., 2017; Vilcacundo et al., 2017).

Phaseolus vulgaris L. belongs to the Fabaceae family. It is an important crop in legume grains with a high protein content, with an important consumption in different places, such as South America, Central America, and Africa. In 2011, the world production of these beans was more than 20 million tons, the area dedicated to this crop was around 30 million hectares (LunaVital et al., 2015). Phaseolus vulgaris seeds have an important nutritional and biological value in the human diet. Phaseolus vulgaris has a protein content ranging from $16 \%$ to $33 \%$, a big fraction represented by the storage protein phaseolin $(30 \%$ to $50 \%$ ) and lectins (10\% to 12\%) (Boschin et al., 2014; GarcíaMora et al., 2015, Torres et al., 2016). Phaseolin contains trimeric proteins that belong to the $7 \mathrm{~S}$ vicilin class. Different authors have described antihypertensive, antitumoral, antifungal, and antioxidant activities of hydrolysates obtained from $P$. vulgaris L. (Akıllığlu and Karakaya, 2009; Lin and Lai, 2006; Mamilla and Mushra, 2017; Pazmiño et al., 2018).

Lipid oxidation is an important issue for the food industry because many processed products contain fats of animal and vegetable origin in their formulations. Fats produce food spoilage. It is known that linoleic acid is prone at process of oxidation during the storage of processed food (Barden and Decker, 2016). Thiobarbituric acid reactive substances (TBARS) in vitro method can serve as screening to select antioxidant samples to be evaluated in an in vivo model that allows to understand the mechanism of action and the implication of the reduction of reactive substances (ROS)

Zebrafish (Danio rerio) is an emerging animal model with many uses in medicine, pharmacy, molecular biology, and biotechnology and recently in food science as its genomic expression for certain diseases is similar to humans. It is an easyto-use, low-cost, and fast-growing animal model with few ethical restrictions for laboratory management (Sprague et al., 2006). Zebrafish is a model that allows to evaluate the inhibition of ROS substances and the inhibition of TBARS lipid peroxidation using zebrafish embryos and larvae. At the same time, it allows to evaluate the toxicity of the molecules studied. Rat and mouse animal models are used to evaluate TBARS and ROS inhibition but present the disadvantages of the ethical restrictions, high cost, and sacrifice of the animals used. In the zebrafish model, five-day post-fertilization larvae are used.

The aim of this research was to produce Red Bean Protein Concentrate, RBPC, from P. vulgaris and evaluate the digestibility using standardized in vitro digestion methods (Minekus et al., 2014). The antioxidant capacity and inhibition of lipid peroxidation in vitro and in vivo (zebrafish) were also evaluated.

\section{MATERIAL AND METHODS}

\section{Isolation of red bean protein concentrate (RBPC)}

Phaseolus vulgaris L. seeds were obtained from a germplasm bank at the State Bolivar University, campus Alpacha (Guaranda-Ecuador). RBPC was prepared according to Poveda et al. (2016). The defatted flour was suspended in water $(1: 10, w: v)$ at $\mathrm{pH}$ 8.0. The suspension was centrifuged at $4500 \times \mathrm{g}$ during 30 minutes. The precipitate was removed, and the $\mathrm{pH}$ of the solution was adjusted at $\mathrm{pH}(3.0,4.0,5.0,6.0$, and 7.0). Finally, the $\mathrm{pH}$ of the precipitate was neutralized and lyophilized. It was kept frozen until its use. The RBPC protein content was determined using the Dumas method (Serrano et al., 2013). Moisture, lipids, total fiber, soluble solids, and ash of RBPCs were determined according to AOAC 2012 using the methods: 950.10, 930.09, 985.29, 923.09, and 942.05. The carbohydrate content was also determined using the method described by AOAC (2012).

\section{RBPC in vitro gastrointestinal digestion}

The in vitro gastrointestinal simulation was made according to Minekus et al. (2014) with minor changes for this study. The oral phase was not considered in this study. RBPC (5.0 $\mathrm{mg} / \mathrm{ml}$ ) was subject to a gastric phase digestion at $\mathrm{pH} 3.0$ using pepsin enzyme which was added to $2,000 \mathrm{U} / \mathrm{ml}$ at $37^{\circ} \mathrm{C}$ for 2 hours. Then, the $\mathrm{pH}$ was adjusted at $\mathrm{pH} 7.0$ for the intestinal phase and the pancreatin enzyme was used. The percentage of hydrolysis degree $(\% \mathrm{DH})$ of RBPC hydrolyzed protein was determined according to Adler-Nissen (1979). Gastric and duodenal digests were fractionated using the ultrafiltration method with a hydrophilic cutoff membrane using Vivaspin 500 (GE Healthcare, Little Chalfont, UK). Fractions with molecular weight lower than 3 and $10 \mathrm{kDa}$ were lyophilized and stored at $-20^{\circ} \mathrm{C}$. The protein content of samples was determined using the Lowry protocol.

\section{RBPC characterization and RBPC digests by sodium dodecyl sulfate polyacrylamide gel electrophoresis (SDS-PAGE)}

SDS-PAGE electrophoresis of all the samples was made in a concentration of $12 \%$ polyacrylamide solution in a Mini-Protean electrophoresis system (Bio-Rad, Hercules, CA, USA). The standard proteins $(10-250 \mathrm{kDa})$ were used. Gels were stained for 12 hours with a Coomassie Blue G-250 solution (Cardenas et al., 2018).

\section{RBPC 2-DE electrophoresis analysis}

Nearly, $50 \mu \mathrm{g}$ of sample were dissolved in lysis and rehydration buffers. Samples were loaded on Ready Strip IPG Strips with a $\mathrm{pH}(3.0-10.0)$, using $0.6 \%$ dithiothreitol and $1 \%$ IPG buffer (Bio-Rad). The first-dimensional isoelectric focusing (IEF) was made in a PROTEAN IEF cell (Bio-Rad, Hercules, CA). Strips were submerged in the equilibration solution with $1 \%$ dithiothreitol for 15 minutes at $25^{\circ} \mathrm{C}$ and then was added $2.5 \%$ iodoacetamide to the solution. 2DE (SDS-PAGE), equilibrated strips were loaded on $10 \%(\mathrm{w}: \mathrm{v})$ gels, and were run vertically in a PROTEAN system (Bio-Rad) (Quinteros et al., 2016).

\section{RBPCs RP-UHPLC analysis and RBPC digests}

RBPCs and their digest were analyzed using the RPUHPLC methods, (Agilent 1200 infinity, Agilent Technologies, Waldbron, Germany). The detector uses a wavelength of $214 \mathrm{~nm}$. 
The separation was made using the column (Zorbax EC C18, Agilent Poroshell 120,). The samples were eluted using the lineal gradient method. Samples were eluted at $1.0 \mathrm{ml} /$ minute using a lineal gradient of $0 \%$ to $70 \%$ of organic solvent (Lara et al., 2017). Trifluoroacetic acid was added to the solution to improve the segregation of proteins.

\section{Fourier transform infrared spectroscopy (FTIR)}

RBPCs and gastric and gastrointestinal samples were analyzed using the FTIR spectrometer method (PerkinElmer, FTIR spectrometer Frontier, UK). All the spectrums were obtained by comparison between 32 scans at $4 \mathrm{~cm}^{-1}$ from 4,000 to 650 $\mathrm{cm}^{-1}$ (Zhao et al., 2008). The spectrum data were analyzed using the PerkinElmer Spectrum software (Version 10.4, UK). All the assays were made twice.

\section{Extraction of polyphenols from RBPC}

The extraction of polyphenols from RBPC was carried out according to Hue et al. (2014). Nearly, $0.3 \mathrm{~g}$ of RBPC lyophilized was added to $5 \mathrm{ml}$ of solution with $70 \%$ of methanol, $30 \% \mathrm{H}_{2} \mathrm{O}$, and $0.1 \%$ of formic acid $v / v$. This step of the extraction was made four times. Samples were shaken (Mist10ral MultiMixer; Melrose Park, USA) for 5 minutes, followed by an ultrasound treatment (Cole-Parmer model 8892; Chicago, USA) for 10 minutes. Then, the samples were centrifuged at 5,700 rpm (Damon EC DIVISION; USA) for 10 minutes. The extract of each cycle was collected in $25 \mathrm{ml}$ flasks with a methanol solution.

\section{Total polyphenols content (TPC) from RBPC}

RBPC samples TPC were calculated according to the Singleton and Rossi (1965) method using small adjustments. One milliliter of Follin solution was added.to $1 \mathrm{ml}$ of sample work. At minute three, $1 \mathrm{ml}$ of $\mathrm{Na}_{2} \mathrm{CO}_{3}$ solution was added. The reaction was made in dark conditions for 90 minutes. Then, the absorbance was measured at $725 \mathrm{~nm}$ (Thermo Scientific Evolution 200). Gallic acid was used to make the standard curve at concentrations of $0-0.075 \mathrm{mg} / \mathrm{ml}$. The results were represented as $\mathrm{mg}$ of gallic acid equivalents (GAE)/100g sample.

\section{ABTS analysis}

ABTS method was used according to Arnao et al. (2001) using a $7.4 \mathrm{mM}$ ABTS solution and a $2.6 \mathrm{mM} \mathrm{K}_{2} \mathrm{SO}_{8}$ solution. Ten milliliter of ABTS solution was mixed with $10 \mathrm{ml}$ of $\mathrm{K}_{2} \mathrm{SO}_{8}$ solution for 12 hours at $25^{\circ} \mathrm{C}$ in dark conditions. This solution was diluted by mixing $1 \mathrm{ml}$ with $50 \mathrm{ml}$ of methanol to obtain an absorbance of 1.1 at $734 \mathrm{~nm}$ (Thermo Fisher Scientific Evolution $200 \mathrm{UV} /$ Vis, Waltham, MA USA). Nearly, $150 \mu \mathrm{l}$ of sample were mixed with 2,850 $\mu \mathrm{l}$ of ABTS solution and the mixture was kept at $25^{\circ} \mathrm{C}$ for 2 hours in dark conditions. The blank was prepared in the same form, but methanol was replaced with ABTS. Trolox standard was made with a standard curve. The antioxidant activity was expressed as $\mu \mathrm{moL}$ Trolox equivalents (TE)/g sample.

\section{Oxygen radical absorbance capacity-fluorescein (ORAC-FL) assay}

The worked solution was of $200 \mathrm{ml}$ and had fluorescein (FL) (70 nM), 2,2'-Azobis(2-amidinopropane) dihydrochloride
(AAPH) $14 \mathrm{mM}$, and antioxidant Trolox (0.2-1.6 nmoL). The fluorescence emitted was read for 137 minutes using a FLUOstar OPTIMA plate reader (BMG Labtech, Offenburg, Germany). The assay was controlled using the FLUOstar Control software (version 1.32 R2). Black 96-well microplates (Nunc, Denmark) were used. All the experiments were prepared in three times. ORAC-FL values were represented as $\mu \mathrm{moL}$ of Trolox equivalent (TE)/g sample (Vilcacundo et al., 2018b).

\section{Ferric-reducing antioxidant power assay (FRAP)}

One milliliter of samples was diluted (1:2 and 1:4) and then mixed with $2.5 \mathrm{ml}$ of buffer phosphate ( $\mathrm{pH} 6.6$ ) and $2.5 \mathrm{ml}$ of the potassium ferrocyanide solution $1 \%(\mathrm{w}: \mathrm{v})$. The solution was heated at $50^{\circ} \mathrm{C}$ for 20 minutes. Then, $2.5 \mathrm{ml}$ of trichloroacetic acid at $10 \%(\mathrm{w}: \mathrm{v}), 2.5 \mathrm{ml}$ distilled water and $0.5 \mathrm{ml}$ of ferric chloride at $1 \%(w: v)$, were added. The solution was kept for 30 minutes at $25^{\circ} \mathrm{C}$ (Benzie and Strain, 1996).

The absorbance was measured at $700 \mathrm{~nm}$ by UV-VIS spectrophotometry (Shimadzu Spectrophotometer model 2600, Kyoto, Japan) and Trolox standard was used to standard the curve. The data obtained were expressed as $\mu \mathrm{moL}$ Trolox Equivalents (TE)/g sample.

\section{DPPH assay}

RBPCs, hydrolysates and fractions were used to evaluate their antioxidant activity with the DPPH method. The ability to capture free radicals by antioxidants was analyzed using the radical species DPPH according to Brand-Williams et al. (1995), measuring the decrease of absorbance at $517 \mathrm{~nm}$ spectrophotometrically (SP-2100UV/SP spectrophotometer, China). Each assay was made in triplicate with the value of activity represented as $\mathrm{mg}$ of Trolox equivalents (TE)/100 g sample.

\section{In vitro thiobarbituric acid reactive substances (TBARS)}

RBPCs and digest were used to calculate \% TBARS. Nearly, $0.5 \mathrm{~g}$ of sacha inchi oil was oxidized by heating. Samples $(2.0 \mathrm{mg} / \mathrm{ml})$ were added in the oil and were heated at $30^{\circ} \mathrm{C}$ for 48 hours. Butylhydroxytoluene (BHT) was used as a positive control. One milliliter of sample was mixed with $1 \mathrm{ml}$ of the $1 \%$ thiobarbituric acid (TBA) solution. The solution was heated at $95^{\circ} \mathrm{C}$ for 1 hour. The absorbance was measured at $532 \mathrm{~nm}$ (Thermo Scientific Evolution 200). \% TBARS was represented as $\%$ TBARS $=A_{\mathrm{s}} / A_{\mathrm{b}} \times 100$, where $A_{\mathrm{b}}$ is the absorbance of blank and $A_{\mathrm{s}}$ is the absorbance of the sample (Carrillo et al., 2016b).

\section{In vivo TBARS evaluation in zebrafish}

Thirty larvae of zebrafish were incubated in 24-well plates with the samples. Lipid peroxidation was started with $1 \mathrm{ml}$ of $1.5 \%$ ethanol for 8 hours at $28^{\circ} \mathrm{C}$. Then, $500 \mu \mathrm{l}$ of Tween $0.1 \%$ was added. Larvae were homogenized (T25 basic Ultra Turrax IKA, Thermo Fisher Scientific, Germany). One milliliter of $1 \%$ TBA was added and the solution was heated at $95^{\circ} \mathrm{C}$ for 1 hour. Absorbance of the solution was measured at $532 \mathrm{~nm}$ (Thermo Scientific Evolution 200, Germany). \% TBARS were expressed as $\%$ TBARS $=\left[1-\left(A_{\mathrm{b}}-A_{\mathrm{s}}\right) / A_{\mathrm{b}} \times 100\right]$, where $A_{\mathrm{b}}$ is the absorbance of blank and $A_{\mathrm{s}}$ is the absorbance of the sample (Carrillo et al., 2016a). 


\section{Incubation of zebrafish embryos with AAPH reactive}

Then, 7-9 hours post-fertilization (7-9 hpf), embryos (group $=$ six embryos) were transferred to a 12-well plate and submerged in an osmotic embryo medium E2 $1 \mathrm{X}(15 \mathrm{mM} \mathrm{NaCl}, 0.5$ $\mathrm{mM} \mathrm{KCl}, 1.0 \mathrm{mM} \mathrm{CaCl} 2 \mathrm{H}_{2} \mathrm{O}, 50 \mu \mathrm{M} \mathrm{Na}_{2} \mathrm{HPO}_{4}, 150 \mu \mathrm{M} \mathrm{KH}_{2} \mathrm{PO}_{4}$, $10 \mathrm{mM} \mathrm{MgSO}_{4} 7 \mathrm{H}_{2} \mathrm{O}, 0.7 \mathrm{mM} \mathrm{NaHCO}$, and $0.5 \mathrm{mg} / \mathrm{l}$ of methylene blue dissolved in distillated water) containing $1 \mathrm{ml}$ of vehicle $(0.1 \%$ DMSO) with samples for 2 hours. After embryos were treated with 25 mM AAPH or treated with AAPH plus samples for up to 24-hour post-fertilization (24 hpf) (Cunliffe, 2003).

\section{Evaluation of ROS formation in zebrafish embryos}

Formation of ROS in zebrafish embryos was analyzed using an fluorescent assay 2,7-dichlorofluorescein diacetate (DCFH-DA). DCFH-DA is changed intracellularly in high fluorescent compound dichlorflouorescein (DCF) (Rosenkranz et al., 1992). The embryos were treated with $0.1 \%$ dimethyl sulfoxide (DMSO) to permeabilize the chorion of zebrafish eggs. At 3-4 hpf, the embryos were incubated with the samples. Two hours later, $25 \mathrm{mM}$ AAPH was added and was incubated for 24 hours. The embryos were transferred into 96-well plates and treated with a DCFH-DA solution $(2.0 \mu \mathrm{l} / \mathrm{ml})$. The plates were incubated for 2 hours in the dark at $28.5^{\circ} \mathrm{C}$. Then, the chorion was removed with the help of tweezers. The image of stained embryos was registered using a fluorescent microscope (Leica DM1000 LED, Wetzlar, Germany), equipped with a camera Moticam 2000 (Taiwan, China).

\section{Statistical analysis}

Results are expressed as means \pm standard deviation of five replicates for assay. The differences were analyzed using ANOVA one-way followed by the Tukey test. All the results were considered statistically significant at $p<0.05$ using the software GraphPad Prism 4.

\section{RESULTS AND DISCUSSION}

\section{$\%$ of RBPC yield and \% of RBPC protein content}

In this study, RBPC from $P$. vulgaris L. cultivated in Ecuador was obtained. The protein concentrates from red bean were obtained by the alkaline method $(\mathrm{pH} \mathrm{8.0)}$ and isoelectric precipitation $(\mathrm{pH} 3.0-\mathrm{pH} 7.0)$. At a $\mathrm{pH} 4.0$ of precipitation in the RBPC isolation, a $14.91 \%$ yield was obtained, this was the highest value, followed by the RBPC obtained at $\mathrm{pH} 5.0$ with a yield value of $13.69 \%$. These $\mathrm{pH}$ values are near the isoelectric point of the proteins ( $\mathrm{pI} 4.5$ ). This is the reason that explains high yields.

RBPC protein content was determined using the Dumas method (Table 1). Red bean flour presents a $23.71 \%$ protein content. All the protein concentrates presented higher protein contents than the red bean flour. $\mathrm{RBCP}$ at $\mathrm{pH} 7.0$ present a higher value with $72.68 \%$ and the lower value was for the $\mathrm{RBCP}$ at $\mathrm{pH}$ 5.0 with a value of $57.38 \%$ of protein content. These samples present statistical differences $(p<0.05)$. The presence of other components in RBPCs was also determined. For example, RBPC at $\mathrm{pH} 7.0$ present $72.68 \%$ of protein, $0.84 \%$ of lipids, $0.86 \%$ of fiber, $5.5 \%$ of ash, $3.20 \%$ of moisture, $1.23 \%$ of soluble solids, and $15.69 \%$ of carbohydrates.
Characterization of RBPC by RP-UHPLC, SDS-PAGE, and 2DE electrophoresis analysis

RBPCs were analyzed using a RP-UHPLC (Fig. 1). All the RBCPs present similar profiles of peaks observed in the chromatogram. This indicates that proteins obtained at the $\mathrm{pHs}$ used were the same proteins. These peaks were named P1-P3. $\mathrm{P} 1$ and P3 peaks were the main fractions present in the protein concentrates. P3 from RBPC present a higher intensity of absorbance, this indicates that this fraction is very soluble at a neutral $\mathrm{pH}$ ( $\mathrm{pH} 7.0)$.

RBPCs were also analyzed using the SDS-PAGE electrophoresis (Fig. 2). In the gel, it can be observed that the proteins profile obtained is the same at all the $\mathrm{pHs}$ assayed in this study. Bands were observed from 15 to $100 \mathrm{kDa}$ molecular weights. Bands with 45 and $50 \mathrm{kDa}$ were the ones with the highest intensity in all the $\mathrm{pHs}$ assayed. The intensity increases when $\mathrm{pH}$ increases, at $\mathrm{pH} 7.0$ bands of 45 and $50 \mathrm{kDa}$ are very intense, showing a correlation with the high percentage of protein content (72.68\%) determined with the Dumas method. The bands (45 and $50 \mathrm{kDa}$ ) were identified as vicilin (globulin fraction). Also, three bands were identified with high molecular weights of 60,80 , and $100 \mathrm{kDa}$ approximately. Other three bands were identified with mass of $15,20,25$, and $30 \mathrm{kDa}$, these bands can be lectin proteins from $P$. vulgaris.

RBPC at $\mathrm{pH} 7.0$ was analyzed using the 2-DE electrophoresis method. Figure 3 shows a RBPC proteins profile at $\mathrm{pH}$ 7.0. This profile shows two bands with high intensity and molecular weights between 50 and $60 \mathrm{kDa}$. Two bands show 26 spots in the profile, these bands can be phaseolin polypeptides. Lopez-Pedrouso et al. (2014) reported a protein profile of common beans from MesoAmerican and the Andean regions using the 2-DE electrophoresis, with two bands with mass corresponding to 40 to $60 \mathrm{kDa}$, these bands were identified as phaseolin subunits. They reported variations in the number of spots present in the varieties (Lopez-Pedrouso et al., 2014).

Montoya et al. (2008) and (2010) reported the protein profile of different variety of Phaseolus. They reported high content of globulins and reported 2-6 bands between $40 \mathrm{kDa}$ and $54 \mathrm{kDa}$, they identified these bands as Vicilin (7S globulin). Carrasco-Castilla et al. (2012) reported protein profiles of $P$. vulgaris. They identified 10 protein bands with mass ranging from 15 to $200 \mathrm{kDa}$ in the sample. The 41 and $46 \mathrm{kDa}$ bands correspond to the phaseolin subunits and the most abundant proteins. The bands of $15 \mathrm{kDa}, 18 \mathrm{kDa}, 25 \mathrm{kDa}$ and $32 \mathrm{kDa}$ were identified as lectin familiy proteins.

Table 1. Proteins content of flour and concentrates from red bean. \% Yield of RBPC.

\begin{tabular}{lcc}
\hline Sample & $(\boldsymbol{\%})$ Protein \pm SD & \% Yield RBPC \\
\hline RB Flour & $23.71 \pm 0.13^{\mathrm{a}}$ & \\
RBPC pH 3.0 & $64.47 \pm 0.01^{\mathrm{b}}$ & $12.91^{\mathrm{b}}$ \\
RBPC pH 4.0 & $65.53 \pm 1.90^{\mathrm{c}}$ & $14.43^{\mathrm{d}}$ \\
RBPC pH 5.0 & $57.38 \pm 0.00^{\mathrm{d}}$ & $13.69^{\mathrm{c}}$ \\
RBPC pH 6.0 & $65.00 \pm 0.20^{\mathrm{e}}$ & $8.66^{\mathrm{a}}$ \\
RBPC pH 7.0 & $72.68 \pm 0.10^{\mathrm{c}}$ & $12.70^{\mathrm{b}}$ \\
\hline
\end{tabular}

Data analyzed by one-way ANOVA and followed by Tuckey's test. Different letter represents significant differences between sample as $p<0.05(n=5)$. 

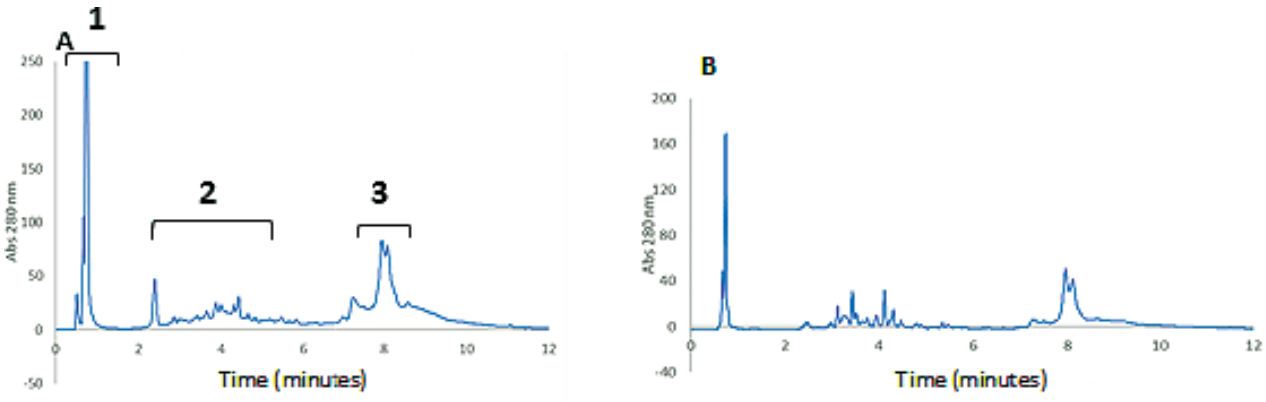

C
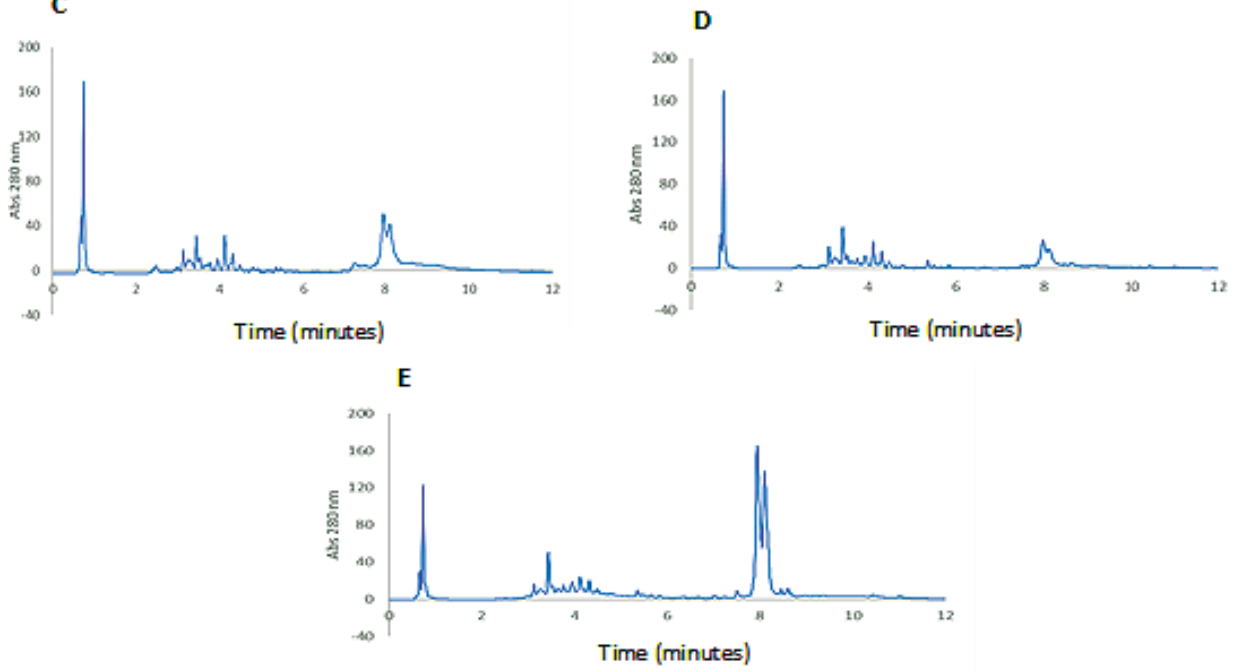

Figure 1. RP-UHPLC analysis of red bean concentrate (RBPC). (A) RBPC at $\mathrm{pH} 3.0$, (B) RBPC at $\mathrm{pH} 4.0$, (C) RBPC at $\mathrm{pH} 5.0$, (D) RBPC at $\mathrm{pH} 6.0$, and (E) RBPC at $\mathrm{pH} 7.0$.

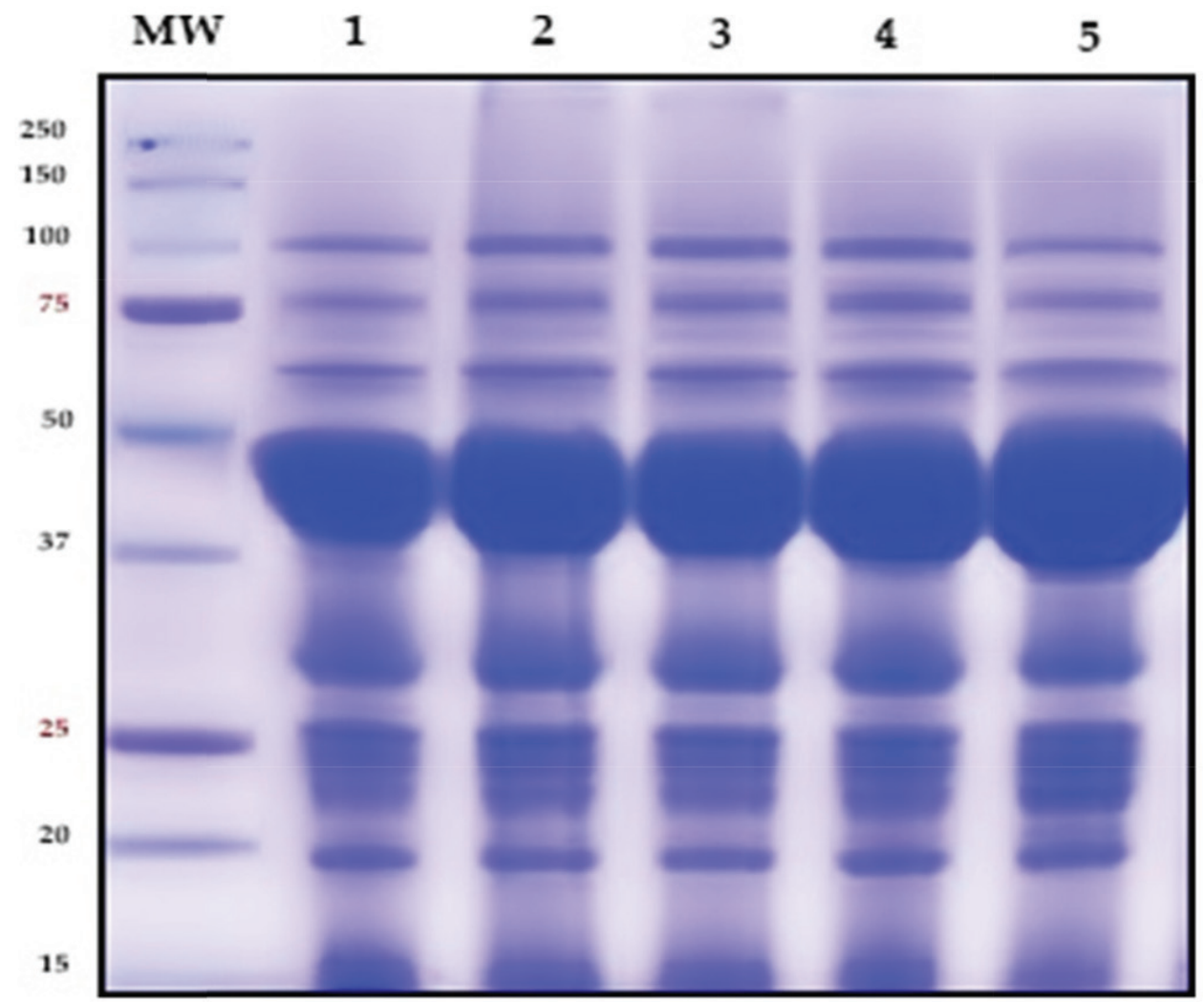

Figure 2. SDS-PAGE electrophoresis analysis of RBPC. Lane 1: RBPC at $\mathrm{pH} 3.0$, lane 2: RBPC at $\mathrm{pH}$ 4.0, lane 3: $\mathrm{RBPC}$ at $\mathrm{pH} 5.0$, lane 4: RBPC at $\mathrm{pH} 6.0$, and lane 5: RBPC at $\mathrm{pH} 7.0$. MW (molecular weight standard). 


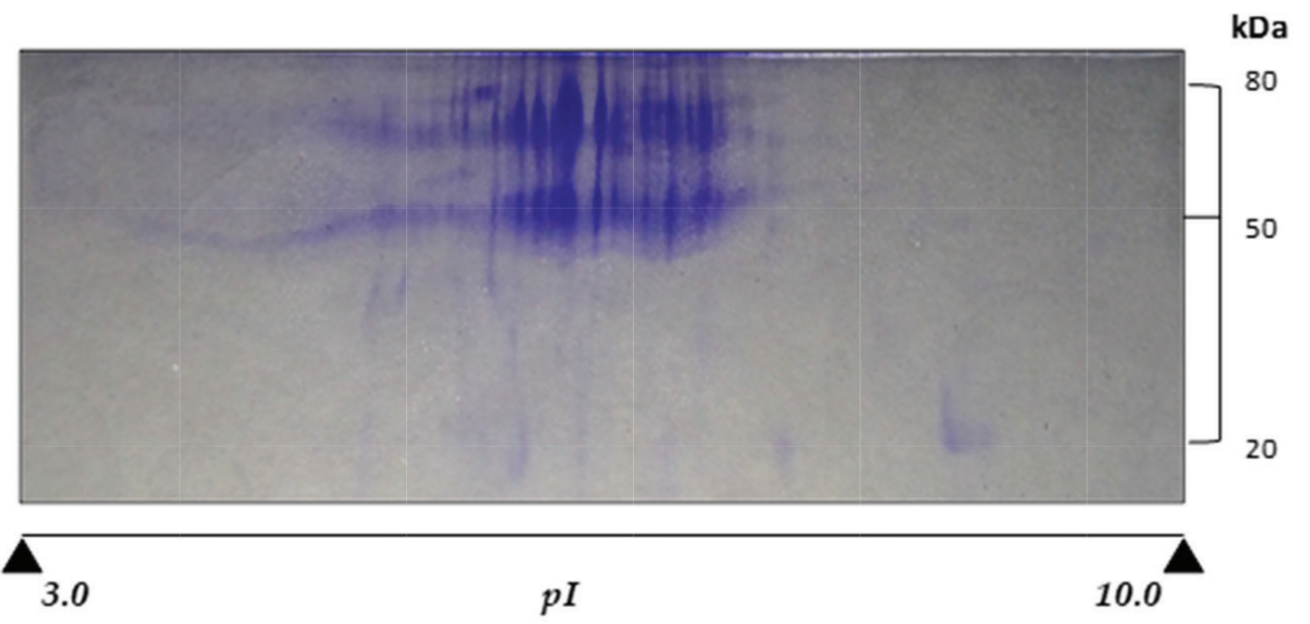

Figure 3. 2-DE electrophoresis analysis of RBPC at $\mathrm{pH}$ 5.0. Positions of spots according at their isoelectric point (pI) and molecular mass $(\mathrm{Mr})$ are shown.

A

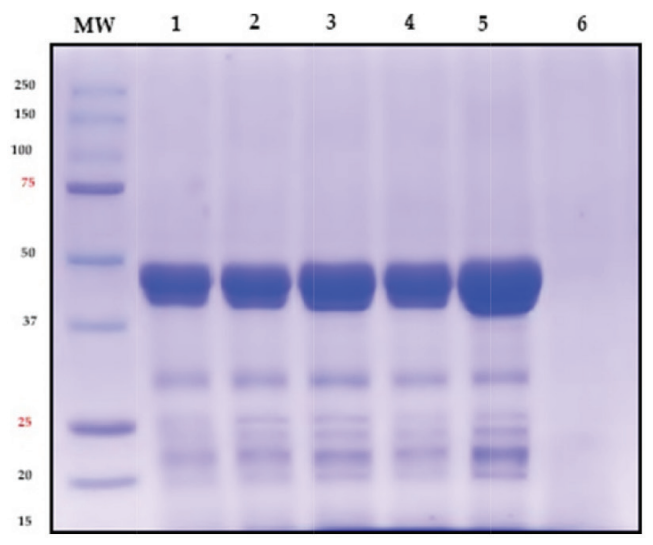

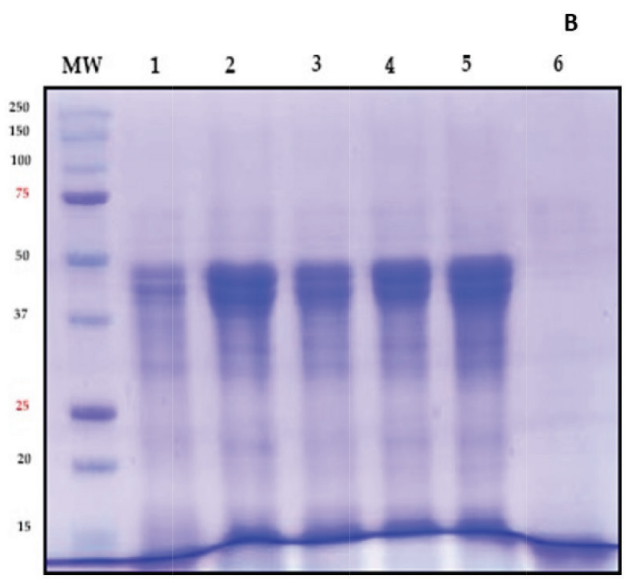

Figure 4. SDS-PAGE electrophoresis analysis of RBPC under simulated gastrointestinal digestion. A) gastric digest and B) duodenal digest. Lane 1: RBPC at $\mathrm{pH} 3.0$, lane 2: $\mathrm{RBPC}$ at $\mathrm{pH} 4.0$, lane 3: $\mathrm{RBPC}$ at $\mathrm{pH}$ 5.0, lane 4: RBPC at $\mathrm{pH}$ 6.0, and lane 5: RBPC at $\mathrm{pH}$ 7.0. MW (molecular weight standard).

García-Mora et al. (2015) reported a protein profile from $P$. vulgaris $\mathrm{L}$. var. pinto, with bands between 10 and 97 $\mathrm{kDa}$. Bands with molecular weights of $25 \mathrm{kDa}, 45 \mathrm{kDa}$, and 50 $\mathrm{kDa}$ were identified as phaseolin. Phytohemagglutinins ( $32 \mathrm{kDa})$, $\alpha$-amylase inhibitor $(18 \mathrm{kDa})$, and $\alpha$-amylase $\beta$ subunit $(15 \mathrm{kDa})$ were identified in the pinto bean protein concentrate. Our RBPCs protein profiles, from to $100 \mathrm{kDa}$, are similar to the ones reported by these authors, phaseolin was identified with the same molecular weight 45 and $50 \mathrm{KDa}$.

Hall et al. (1999) reported three isolated bands of common beans identified as phaseolin subunits with molecular weights of 43, 47, and $53 \mathrm{kDa}$. Felsted et al. (1981) reported lectin subunit from $P$. vulgaris with a molecular weight of $32 \mathrm{kDa}$. Also, protease inhibitors have been reported with molecular weights of $10 \mathrm{kDa}$ and $\alpha$-Amilase inhibitor with a mass of 12.4, 15.2, 33.6, and $45 \mathrm{kDa}$ in P. vulgaris (Carrasco-Castilla et al., 2012). The mass of phaseolin proteins described in this study are similar to the masses described by different works on these proteins. The small differences reported in the molecular weights of proteins from $P$. vulgaris $\mathrm{L}$. are due to the high genetic variety existing in these plants.

\section{RBPC digests under simulated gastrointestinal digestion}

In this study, RBPCs at different $\mathrm{pHs}(\mathrm{pH} 3.0-\mathrm{pH}$ 7.0) were subjected to a simulated gastrointestinal digestion using an in vitro method to determine the in vitro digestibility following the harmonized protocol according to Minekus et al. (2014). RBPC gastrointestinal digests were analyzed using the SDS-PAGE electrophoresis method.

\section{Gastric phase digestion}

Figure 4a shows the RBPC protein profile with bands of molecular weights from 15 to $50 \mathrm{kDa}$. RBPCs were hydrolyzed with pepsin at $\mathrm{pH} 3.0$ for 2 hours. In the gastric phase, all the RBPCs present similar profile of hydrolysis with pepsin. Bands of 60,80 , and $100 \mathrm{kDa}$ were totally hydrolyzed with pepsin. Pahseolin fraction $(50 \mathrm{kDa})$ presents partial hydrolysis in all the RBPC assayed, this band contains two bands overlapping in the 

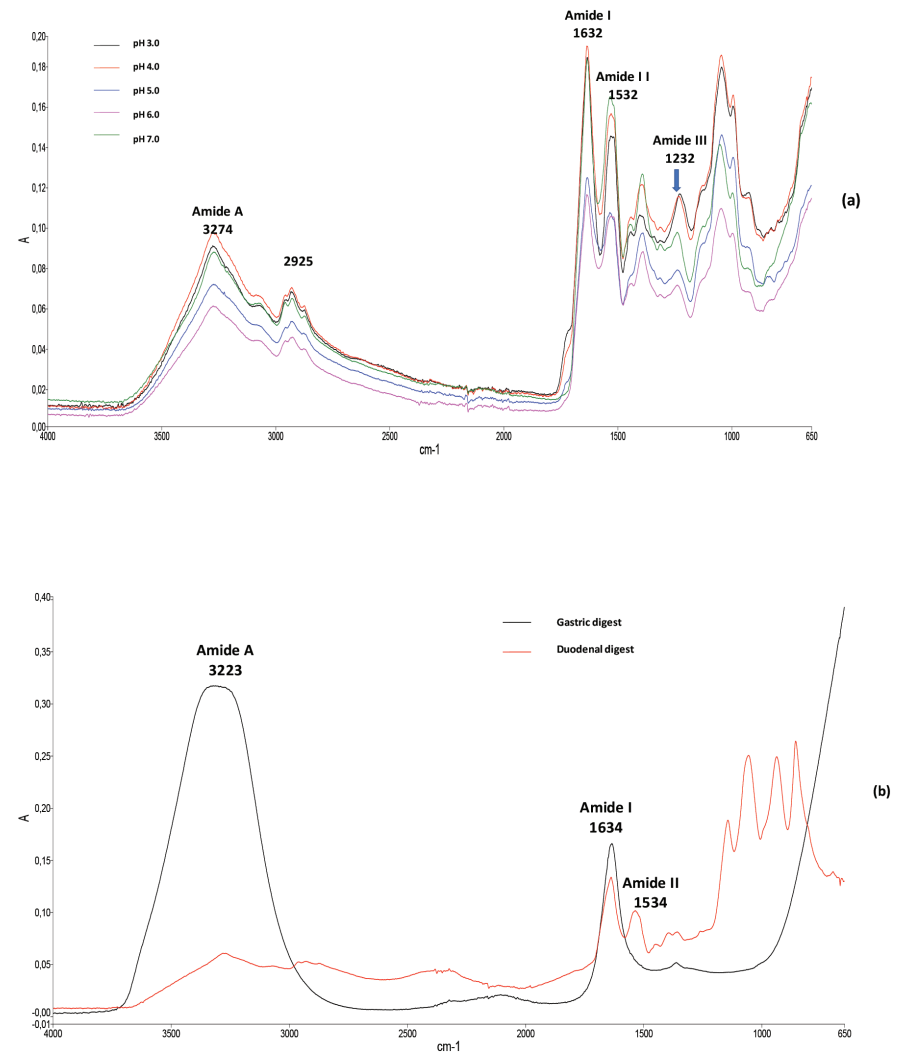

Figure 5. FTIR analysis of RBPC and gastrointestinal digests. (a) RBPC at $\mathrm{pH}$ 3.0 to $\mathrm{pH} 7.0$ and (b) gastric and duodenal digests of RBPC.

gel. The lectins bands of low molecular weight $(15,20,25$, and 30 $\mathrm{kDa}$ ) also present resistance to gastric hydrolysis with the pepsin enzyme. \% DH of gastric digests of RBPCs was determined, showing values from $10 \%$ to $12 \% \mathrm{DH}$. RBPC at $\mathrm{pH} 3.0$ and $\mathrm{pH}$ 6.0 presents higher values with $11.85 \%$ and $12 \% \mathrm{DH}$, respectively.

\section{Duodenal phase digestion}

RBPCs were hydrolyzed with pepsin and pancreatin at $\mathrm{pH} 7.0$ for 2 hours in the presence of bile salt. In the duodenal phase, the phaseolin (50-kDa band) present resistance to hydrolysis with pepsin and pepsin/pancreatin preparation (Fig. 4b). Other bands of high and low molecular weights were hydrolyzed in this phase. Phaseolin protein from $P$. vulgaris presents resistance to gastric and gastrointestinal hydrolysis under the simulated gastrointestinal in vitro method. RBPC obtained at $\mathrm{pH} 3.0$ present higher hydrolysis with pepsin and pepsin/pancreatin. RBPCs \% $\mathrm{DH}$ in duodenal digest was determined with a value from $74.58 \%$ to $75.60 \% \mathrm{DH}$. RBPC at $\mathrm{pH} 3.0$ and $\mathrm{pH} 5.0$ present a higher value with $75.60 \%$ and $74.93 \% \mathrm{DH}$, respectively. All the RBPCs gastrointestinal digest were higher than the RBPCs gastric digest.

Different in vitro hydrolysis methods were used to evaluate hydrolysis of common bean seeds. There are differences in the $\% \mathrm{DH}$ reported in the studies. These differences must be due to the type and variety of seeds, geographic position of the cultivar and the differences in the method of hydrolysis and enzymes used, time of incubation, $\mathrm{pHs}$ of simulation, temperature, proportion of enzymes, and combination of enzymes. For example, Montoya et al. (2008) and (2010) reported hydrolysis of phaseolin isolated treated thermally and not treated thermally of 43 varieties hydrolyzed with pepsin dissolved in $\mathrm{HCl}$ at $\mathrm{pH} 2.0$ incubated for 0,30 , and 120 minutes and hydrolyzed with pepsin and pancreatin dissolved in a phosphate buffer at $\mathrm{pH}$ 7.5. In the gastric phase at 120 minutes of incubation with pepsin, the $\% \mathrm{DH}$ was $5.2 \%$ in the unheated sample and $7.5 \%$ in the heated sample. In the duodenal phase, at 360 minutes of incubation with pepsin and pancreatin, the $\% \mathrm{DH}$ was $11 \%$ to $27 \%$ for the unheated sample, and $57 \%$ to $96 \%$ for the heated sample. The gastrointestinal digest presents a high $\% \mathrm{DH}$ but the results were different depending on the variety of $P$. vulgaris used.

Torruco-Uco et al. (2009) reported hydrolysates of $P$. vulgaris from Mexico obtained with Alcalase and Favourzyme for 30 minutes. They found a $\%$ DH of 49.48 and 26.05 , respectively. Valdez-Ortiz et al. (2012) reported \% DH of three varieties of sulfur yellow bean (P. vulgaris) Azufrado Higuera, Azufrado Noroeste, and Azufrado Regional hydrolyzed with three different enzymes. They reported that Azufrado Regional present the lowest value for the three enzymes with $38 \%$ (alcalase), 33\% (thermolysine), and $18 \%$ (pancreatin) $\% \mathrm{DH}$.

\section{Characterization of RBPC and RBPC digest by FTIR analysis}

RBPCs, gastric digest, and gastrointestinal digest were analyzed using the FTIR technique with wavelengths from 4,000 to $650 \mathrm{~cm}^{-1}$. Figure $5 \mathrm{~A}$ showed relevant peaks at 1,632, 1,532, and $1,232 \mathrm{~cm}^{-1}$, characteristic of amide I region $(\mathrm{C}=\mathrm{O})$, amide II region (N-H bending), and amide III region (C-N and N-H stretching) typical when proteins are identified. The region between 3,000 and $3,500 \mathrm{~cm}^{-1}$ corresponds to Amide A region. Peaks range from 1,460 to $1,380 \mathrm{~cm}^{-1}$ was attributed to the symmetric and asymmetric bending vibrations of the methyl group. The amide I band $\left(1,632 \mathrm{~cm}^{-1}\right)$ presents a high absorption band of proteins, thus is used as a model of protein secondary structure. This band presents stretching vibration of $\mathrm{C}=\mathrm{O}$ bonds $(70 \%-85 \%)$ and is strongly related to the conformation of the polypeptide backbone (Liu et al., 2014; Luján-Facundo et al., 2015). RBPC at pH 3.0, $\mathrm{pH} 4.0$, and $\mathrm{pH} 7.0$ shows strong intensity in the band 1,632 and $15,321 \mathrm{~cm}^{-1}$, this band was identified as amide I and amide II regions. Different authors have reported the characterization of proteins using these bands (Amide I, II, and III). Navarro-Lisboa et al. (2017) reported the identification of proteins from quinoa (Chenopodium quinoa Willd) using the FTIR analysis with the presence of bands $\left(1,632,1,532\right.$, and $\left.1,232 \mathrm{~cm}^{-1}\right)$. These bands were identified as amide I, II, and III, respectively. De la Caba et al. (2012) described the identification of proteins in soybean protein concentrate with the presence of relevant peaks 1,632, 1,532, and $1,230 \mathrm{~cm}^{-1}$ identified as amide I, II, and III. Das et al. (2017) reported the identification of gelatin using the FTIR analysis. They found the relevant peaks 1,630, 1,565, and 1,240 $\mathrm{cm}^{-1}$ identified as amide I, II, and III, respectively.

Figure 5B showed relevant peaks of RBPC gastric digest and $\mathrm{RBPC}$ gastrointestinal digests of $\mathrm{RBPC}$ at $\mathrm{pH}$ 7.0. The spectrum profiles of FTIR analysis were different. RBPC gastrointestinal digest shows peaks with higher intensity. Peaks were identified at 1,634 and $1,534 \mathrm{~cm}^{-1}$ corresponding to amide I and amide II, respectively. Gastric digest presented no typical peaks of amide II and amide III. The only peak identified was the one at $1,634 \mathrm{~cm}^{-1}$, corresponding to the amide I region. However, this peak presented 
a lower intensity than the gastric digest. This fact suggests that the gastric digest presented a low hydrolysis with a correlation with the result of the SDS-PAGE electrophoresis and the \% DH. The region from 3,500 to $3,000 \mathrm{~cm}^{-1}$ shows the highest intensity in gastric digest. FTIR analysis can be used to characterize the gastric and gastrointestinal hydrolysates.

These hydrolysates allow to identify the amide regions used as typical regions used to identify intact proteins.

\section{RBPC and digests antioxidant activity}

Antioxidant activity in fresh fruits, vegetables, legumes and their products, and foods has been described for in vitro and in vivo studies, including using the ABTS, FRAP, TBARS, and ORAC-FL methods. ORAC-FL assay is considered as the most relevant antioxidant method, using a biologically relevant radical source. These antioxidant methods present different results depending of crop species and laboratories. Ou et al. (2002) reported no correlation of antioxidant activity between the FRAP and ORAC methods in a high number of vegetable samples.

The RBPC antioxidant activity $(\mathrm{pH} 3.0-\mathrm{pH} 7.0)$ and their gastric and gastrointestinal digests antioxidant activity were evaluated using the FRAP, ABTS, and ORAC methods.

RBPCs presented values from $45.13 \pm 0.55$ to 95.80 $\pm 0.55 \mu \mathrm{moL}$ of $\mathrm{TE} / \mathrm{g}$ per sample using the FRAP method. The highest value corresponds to RBPC at $\mathrm{pH}$ 7.0. Gastric and duodenal digest were more active than RBPCs. For example, duodenal digests presented the highest value with $225.77 \pm 0.03$ $\mu \mathrm{moL}$ of TE/g sample (Table 2).

In the ABTS method, RBPC at $\mathrm{pH} 5.0$ and $\mathrm{pH} 7.0$ presented the highest antioxidant activity with values of 273.66 \pm 0.55 and $257.12 \pm 0.55 \mu \mathrm{moL}$ of $\mathrm{TE} / \mathrm{g}$ per sample respectively (Table 2). Similar results for gastric and duodenal digests were obtained. These digests presented higher antioxidant activity than RBPCs. Duodenal digests presented the highest value with 345.21 $\pm 0.23 \mu \mathrm{moL}$ of TE/g per sample.

The RBPCs antioxidant activity was also evaluated using the ORAC method. Table 2 shows the ORAC method results. RBPC at $\mathrm{pH} 7.0$ presented an ORAC value of $1960 \pm 0.10$ $\mu \mathrm{moL}$ of TE/g sample, this value was the highest ORAC value in RBPCs. Gastric and gastrointestinal digests obtained with pepsin and pepsin/pancreatin presented the highest antioxidant activity. Gastric digest presented a value of $2423 \pm 0.17 \mu \mathrm{moL}$ of TE/g sample and duodenal digest presented a higher value with $3256 \pm$ $0.20 \mu \mathrm{moL}$ of TE/g sample. When using FRAP, ABTS, and ORAC methods, RBPC gastric and duodenal digest were the samples with the highest antioxidant activity. RBPCs presenting value between $68.23 \pm 0.24$ and $71.82 \pm 0.36$ and their hydrolysates present value of $85.42 \pm 0.11$ to gastric digest and $102.33 \pm 0.09$ to duodenal digest. Duodenal digest present higher value of DPPH than other samples (Table 2). Gastric and duodenal digest from RBPCs were fractionated using ultrafiltration membrane of 3 and $10 \mathrm{kDa}$ to determine the effect of mass of the peptides in the antioxidant capacity using the DPPH method. Gastric fractions present the same antioxidant activity (Fig. 6).

García-Mora et al. (2015) described pinto bean protein concentrate and hydrolysates obtained with alcalase and savinase enzymes. Their antioxidant activity was evaluated using the FRAP, ORAC, and ABTS methods. The hydrolysates obtained with savinase also were more active than the pinto bean protein concentrate. The RBPCs values using the ORAC and ABTS and the RBPCs digest were higher than the ones reported by GarcíaMora et al. (2015). RBPCs have a high content of protein and polyphenols compounds, we suggest that the relation of these molecules in RBPCs can be liable of the antioxidant capacity described in this study.

\section{In vitro and in vivo TBARS in zebrafish larvae}

RBPCs and gastric and gastrointestinal digest of RBPC were used to determinate their capacity to inhibit TBARS using the in vitro and in vivo zebrafish larvae models. The activity was expressed as \% of inhibition TBARS. The MDA content was calculated using an MDA standard curve. In vitro TBARS: Figure 7 shows the results of $\%$ of inhibition TBARS using the in vitro model. BHT was used as a control for its strong antioxidant activity and for the wide use in Ecuador in the food industry for conservation of processed food (oils, snacks, and bakery processed foods). BHT was used as a positive control $(0.25 \mathrm{mg} / \mathrm{ml})$ presenting a value of $80.28 \%$ of inhibition in vitro TBARS. RBPCs and gastric and gastrointestinal digests were evaluated at $2.0 \mathrm{mg} /$ $\mathrm{ml}$ concentrations. $\mathrm{RBPC}$ from $\mathrm{pH} 3.0$ to $\mathrm{pH} 7.0$ present a higher percentage than the BHT positive control at all the concentrations assayed. For example, RBPC at $\mathrm{pH} 7.0$ presented at value of $84.76 \%$ of inhibition in vitro TBARS. RBPC gastric digests and duodenal digests presented a higher value of $\%$ of inhibition TBARS than BHT and RBPCs without hydrolysis. These samples presented values of $87.95 \%$ and $93.0 \%$, respectively (Fig. 7).

\section{In vivo TBARS}

The cytotoxicity of RBPCs and their hydrolysates was evaluated using in vivo zebrafish embryos and the larvae model. In

Table 2. Total Polyphenol Content (TPC) and antioxidant activity of RBPC using FRAP, ABTS, ORAC and DPPH methods.

\begin{tabular}{|c|c|c|c|c|c|}
\hline Sample & $\begin{array}{l}\text { TPC (mg GAE } / 100 \mathrm{~g} \\
\text { sample) } \pm \mathrm{SD}\end{array}$ & $\begin{array}{l}\text { FRAP }(\mu \mathrm{moL} \text { TE } / \mathrm{g} \\
\text { sample }) \pm \text { SD }\end{array}$ & $\begin{array}{l}\text { ABTS }(\mu \mathrm{moL} \text { TE } / \mathrm{g} \\
\text { sample }) \pm \text { SD }\end{array}$ & $\begin{array}{c}\text { ORAC ( } \mu \text { moL TE/g sample) } \\
\pm \text { SD }\end{array}$ & $\begin{array}{c}\text { DPPH }(\mu \mathrm{moL} \mathrm{TE} / \mathrm{g} \text { ample }) \\
\pm \text { SD }\end{array}$ \\
\hline RBPC pH 3.0 & $246.15 \pm 0.55$ & $65.70 \pm 0.25$ & $116.19 \pm 0.16$ & $1250 \pm 0.15$ & $68.23 \pm 0.24$ \\
\hline RBPC pH 4.0 & $135.57 \pm 0.55$ & $45.13 \pm 0.42$ & $81.55 \pm 0.14$ & $870 \pm 0.07$ & $70.45 \pm 0.17$ \\
\hline RBPC pH 5.0 & $204.82 \pm 0.00$ & $87.00 \pm 0.28$ & $273.66 \pm 0.02$ & $1320 \pm 0.04$ & $69.66 \pm 0.24$ \\
\hline RBPC pH 6.0 & $161.63 \pm 1.07$ & $81.26 \pm 0.16$ & $142.29 \pm 0.39$ & $1030 \pm 0.12$ & $68.98 \pm 0.22$ \\
\hline RBPC pH 7.0 & $521.66 \pm 0.85$ & $95.80 \pm 0.37$ & $257.12 \pm 0.78$ & $1960 \pm 0.10$ & $71.82 \pm 0.36$ \\
\hline GD & N/D & $146.89 \pm 0.02$ & $297.63 \pm 0.44$ & $2423 \pm 0.17$ & $85.42 \pm 0.11$ \\
\hline DD & N/D & $225.77 \pm 0.03$ & $345.21 \pm 0.23$ & $3256 \pm 0.20$ & $102.33 \pm 0.09$ \\
\hline
\end{tabular}

Data analyzed by one-way ANOVA and followed by Tuckey's test. Different letter represents significant differences between sample as $p<0.05(n=5)$.

GD (gastric digest) and DD (duodenal digest) 


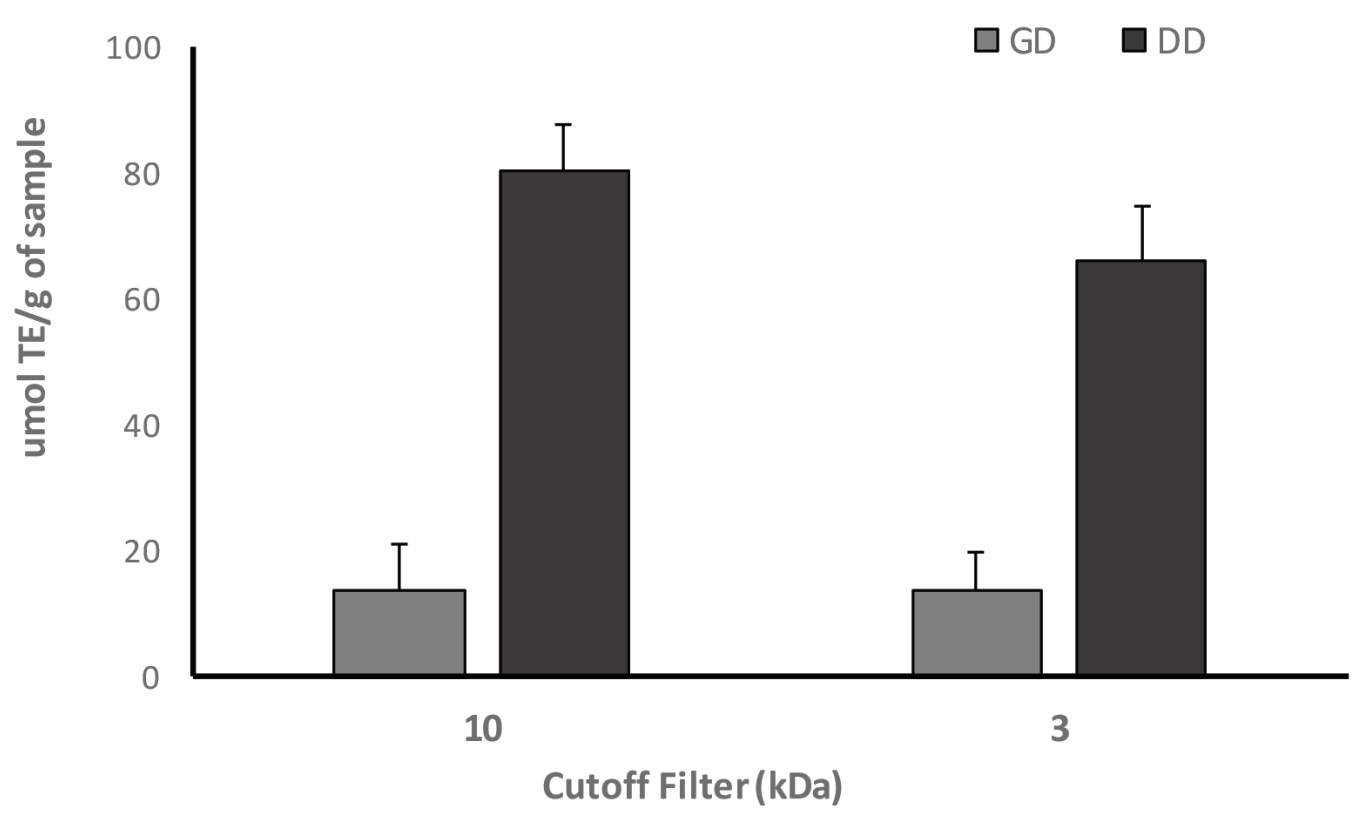

Figure 6. DPPH analysis of fractions of gastric and duodenal digest from RBPC. GD (gastric digest of RBPC at pH 7.0 and $\mathrm{DD}$ (duodenal digest of RBPC at $\mathrm{pH} 7.0$ ).

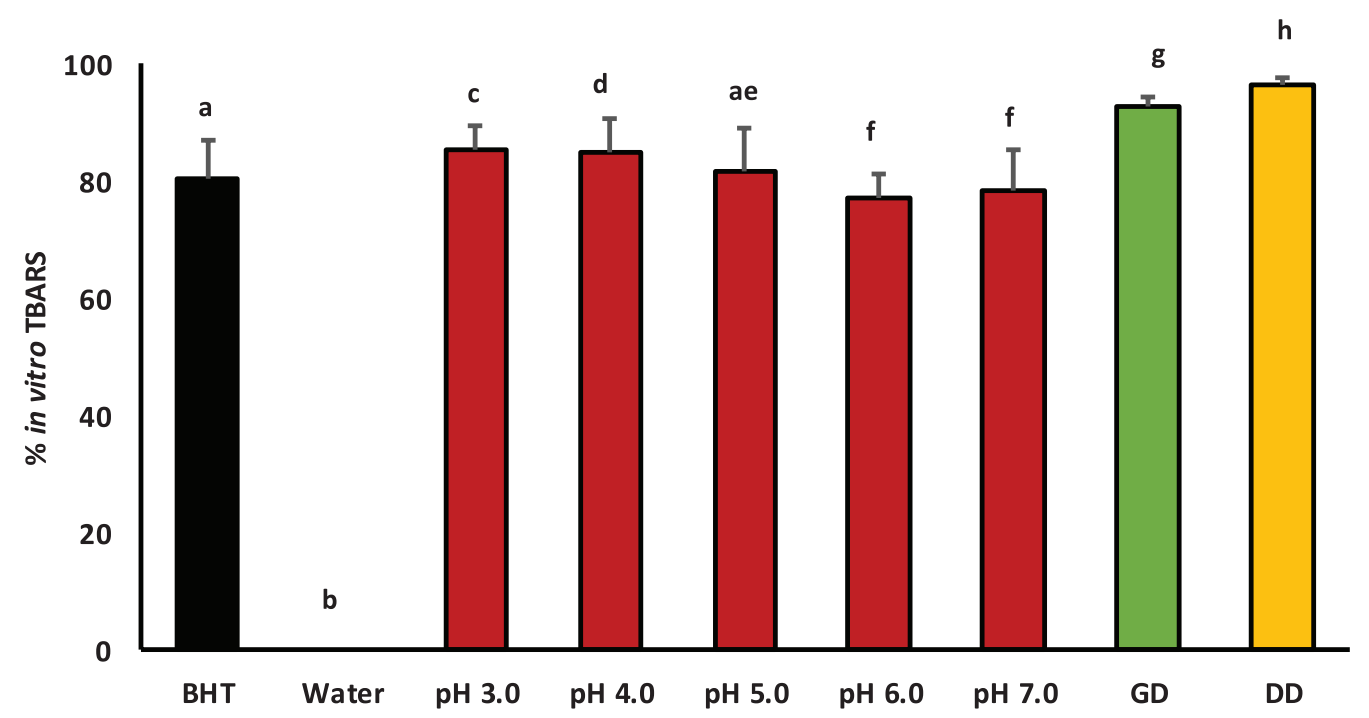

Figure 7. In vitro lipid peroxidation inhibitory activity of RBPC and gastrointestinal digests. BHT (positive control), water (negative control), RBPC (RBPC at pH 3.0-7.0), GD (gastric digest) and DD (duodenal digest). Data were analyzed using one-way ANOVA and followed by Tukey's test. Different letters over bars represent statistical differences between group samples with $p<0.05(n=5)$.

all the samples, $\mathrm{pH}$ was adjusted to 7.0 as low $\mathrm{pHs}$ or high $\mathrm{pHs}$ can kill zebrafish embryos. RBPCs and digest presented inhibition of lipid peroxidation in zebrafish embryos. $\mathrm{RBPC}$ at $\mathrm{pH} 3.0$ presented a value of $53.91 \%, \mathrm{RBPC}$ at $\mathrm{pH} 4.0$ showed a value of $57.21 \%$, RBPC at $\mathrm{pH} 5.0$ had a value of $55.62 \%$, RBPC at $\mathrm{pH} 6.0$ showed a value of $60.31 \%$, and RBPC at $\mathrm{pH} 7.0$ presented a value of $63.06 \%$. Gastric digest presented a value of $79.03 \%$ and duodenal digest presented a value of $86.76 \%$ (Figure 8). After 48 hours of exposure to different concentrations of sample, zebrafish larvae presented an absence of coagulation and the survival percentage was $>95 \%$ of survived larvae. Zebrafish larvae were observed in different times with the help of a stereoscopic microscopy and zebrafish larvae exhibit the same morphology than zebrafish embryos of the control group without the sample. These results indicate that RBPCs and gastric and gastrointestinal digest showed an absence of cytotoxic effect for the development of larvae. Then, after 96 hours of incubation at different concentrations of samples, zebrafish larvae presented no coagulation and the percentage of survival was $100 \%$ of survived larvae. RBPCs and gastric and gastrointestinal digest presented no morphologic damage to the zebrafish larvae. All the larvae were observed in their development stages for 3 months without presenting problems of fertility. Normal eggs, embryos, and larvae were observed. 


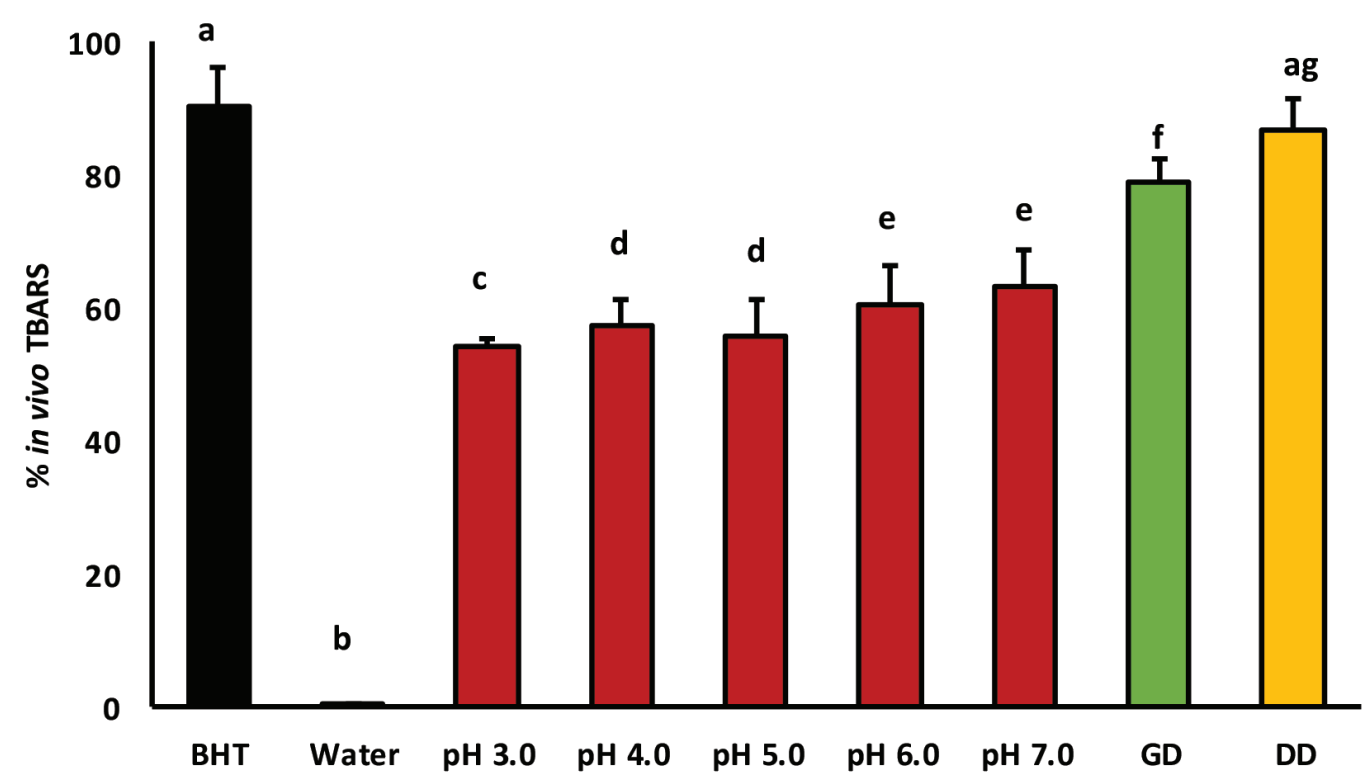

Figure 8. In vivo lipid peroxidation inhibitory activity of RBPC and gastrointestinal digests in zebrafish larvae. BHT (positive control), water (negative control), RBPC (RBPC at pH 3.0 to pH 7.0), GD (gastric digest) and DD (duodenal digest). Data were analyzed using one-way ANOVA and followed by Tukey's test. Different letters over bars represent statistical differences between group samples with $p<0.05(n=5)$.

\section{Protection of RBPC digest in the in vivo model produced for AAPH reactive}

The DCFH-DA fluorescence experiment is the fastest method used to determine and quantify ROS production using in vivo animal models. In the last years, this method has been used in the zebrafish embryos model. It has been reported recently the use of an in vivo antioxidant method in Caco-2 cells and zebrafish embryos using DCFH-DA (2,7-dichlorofluorescein diacetate). This compound is a nonionic substrate and a nonpolar substrate, the cell membrane is hydrolyzed by enzymes with cellular esterase to the non-fluorescent DCFH. DCFH molecule is oxidized to the DFC molecule in the presence of ROS. For this reason, DFC fluorescence represents a measure of ROS in the cells. Kang et al. (2014) reported evaluation of polysaccharide purified from aloe Vera (Aloe barbadensis) to inhibit the production of ROS in zebrafish embryos using DCFH-DA assay (Kang et al., 2014). Lee et al. (2013) described the Ecklonia cava extract with capacity to inhibit the production of ROS in zebrafish embryos using DCFHDA assay. Other authors have described the use of DCFH-DA assay to inhibit ROS in cells model. Goh et al. (2016), described ROS reduction in human cell lines, $\mathrm{HaCaT}$, and human monocytic cell lines, THP-1 from Aronia melanocarpa. Jensen et al. (2015) have described ROS reduction in cells using isolate algae extract. Carrasco-Castilla et al. (2012) reported high antioxidant capacity of the protein hydrolysates determined in Caco-2 cell lines. ROS reduction was quantified using the DCFH-DA assay. Gastric digest and gastrointestinal digest of RBPC at $\mathrm{pH} 7.0$ were used to evaluate their protective effect against oxidative stress in the in vivo zebrafish embryos produced for AAPH reactive.

ROS is used as an important relevant indicator in the determination of damage and oxidative cellular stress. The survival rate of embryos in the experiment was calculated. The non-treated group (basal control) presented a 100\% survival rate of zebrafish embryos. AAPH group presented $75 \%$ live embryos. Gastric and duodenal digests presented 100\% live embryos used in the assay. RBPC, gastric, and gastrointestinal digests antioxidant effects on ROS intensity (DCFH-DA) can be seen in Figure 9. AAPH group shows strong intensity of fluorescence of embryos. RBPC gastric and gastrointestinal digests could inhibit the formation of ROS in zebrafish embryos. Hydrolysates are usually more active than parental proteins due to the formation of bioactive peptides. The antioxidant peptides are usually small fragments with molar weights between 1,500 and 6,000 Da and with an amino acid sequence composed of 5-16 amino acids. The type of amino acid is also determinant in antioxidant activity as the different amino acid tend to be positively charged peptides. Future work can be used to identify the sequences of peptides responsible for antioxidant activity and with the capacity to inhibit ROS in embryos of zebrafish. Other studies are also necessary to determine the mechanism of action of these molecules. Zhao et al. (2004) developed synthetic peptides with aromatic amino acids and positive charge in their sequences: SS-02 (Dmt-DArg-PheLys-NH2; Dmt 2,6-dimethyltyrosine), SS-20 (Phe-D-ArgPheLys-NH2), SS-31 (D-Arg-Dmt-Lys-Phe-NH2), and [3H] SS-02. These peptides were able of inhibiting lipid peroxidation in vitro of linoleic acid and were able of reducing the formation of ROS in the mitochondria of Caco- 2 cells. Carrillo et al. (2016b) described five antioxidant peptides from Hen Egg White Lysozyme (HEWL) with the sequences $\mathrm{f}(109-119)$ VAWRNRCKGTD, f(111-119) WRNRCKGTD, f(122-129) AWIRGCRL, f(123-129) WIRGCRL, and f(124-129) IRGCRL. These peptides inhibited the production of TBARS in the zebrafish model. These peptides have strong positive charge and have aromatic amino acids, such as tryptophan. Carrillo et al. (2016a) reported hydrolysates from native and heat-HEWL with ability to reduce the production of TBARS in the zebrafish model. Vilcacundo et al. (2018a) described 

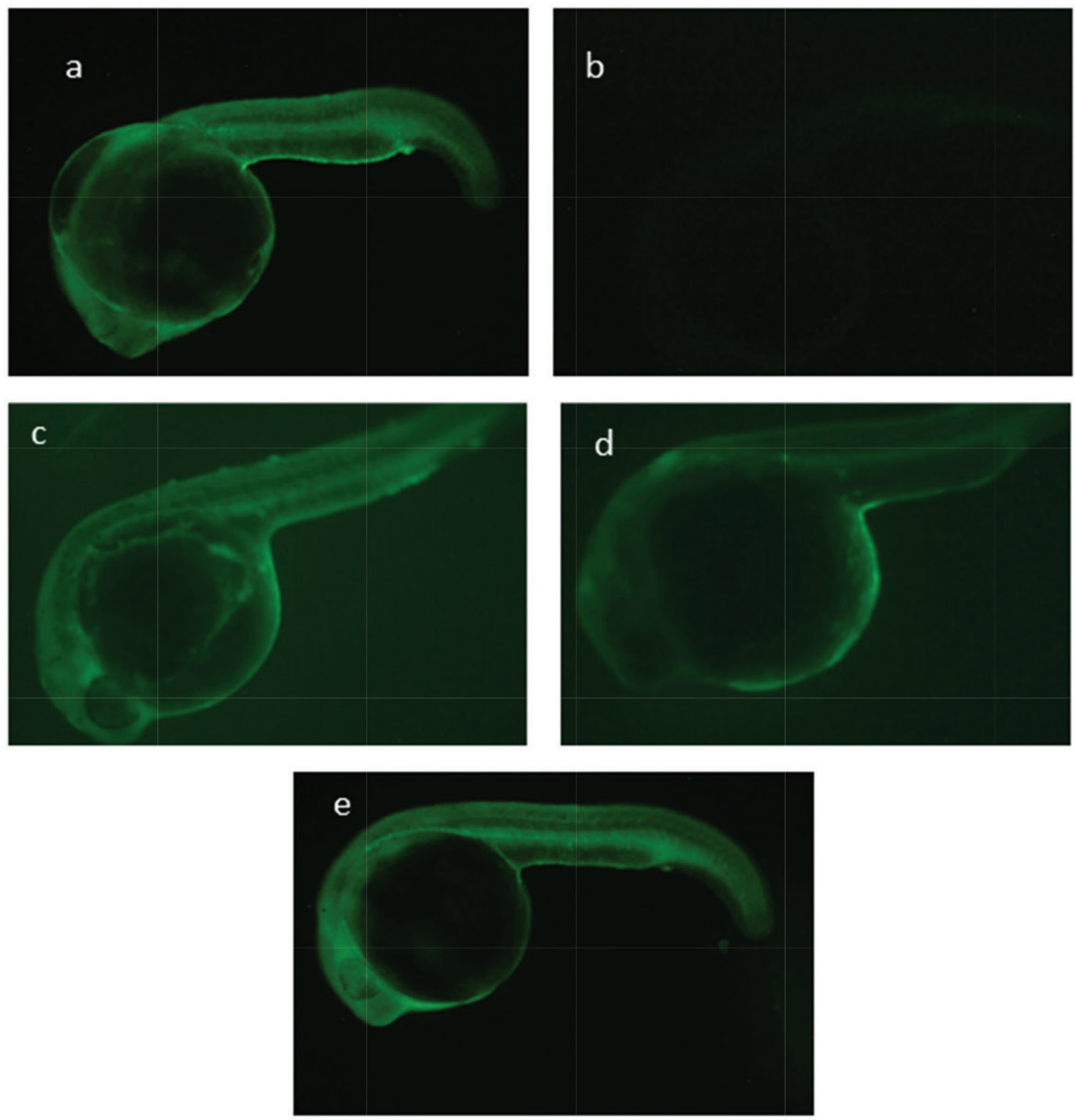

Figure 9. Micrographs of reduction of ROS in zebrafish embryos of RBPC and their gastrointestinal digest. (a) AAPH (positive control), (b) water (control without AAPH), (c) gastric digest of RBPC + AAPH), and (d) duodenal digest of RBPC + AAPH $(n=5)$.

amaranth protein concentrate (APC) and their gastrointestinal digest with the capacity to reduce TBARS in the in vitro and in vivo models (zebrafish larvae and embryos). Gastric digest and duodenal digest present the capacity to reduce ROS in zebrafish embryos using DCFH-DA as a fluorescent agent. These studies indicate that hydrolysates and peptides from food protein can have the capacity to inhibit TBARS in vitro and in vivo with a possible use in the food industry for the conservation of processed oils and food.

It was observed that the intensity of the fluorescence of gastric digest and duodenal digest was lower when compared to the intensity of the group of embryos treated with AAPH. It was observed a higher intensity fluorescence emitted for the group embryos treated with RBPC This fact indicates that RBPC sample produces no protection in the production of ROS. The non-treated group basal control presented the lowest intensity of fluorescence in all the groups. It was difficult to obtain the microphotograph of the basal control group being the intensity extremely low.

The quantification of intensity of the fluorescence of zebrafish embryos was made using software to analyze digital images (ImageJ). The percentage of intensity of fluorescence was compared to the percentage obtained for the positive control (AAPH reactive). $100 \%$ of intensity of fluorescence obtained was assigned to the group of embryos treated with AAPH reactive. Figure 10 shows the $\%$ of intensity of fluorescence of the group of embryos treated with RBPC and gastric digest and gastrointestinal digest of RBPC. RBPC gastric digest at $\mathrm{pH} 3.0$ present a value of intensity of fluorescence of $75.30 \%$ and $\mathrm{RBPC}$ gastrointestinal digests present a value of $66.40 \%$ of intensity of fluorescence when compared to the AAPH signal. RBPC without hydrolysis present $100 \%$ of intensity of fluorescence. This sample presents no protection against oxidation induced for AAPH. The 


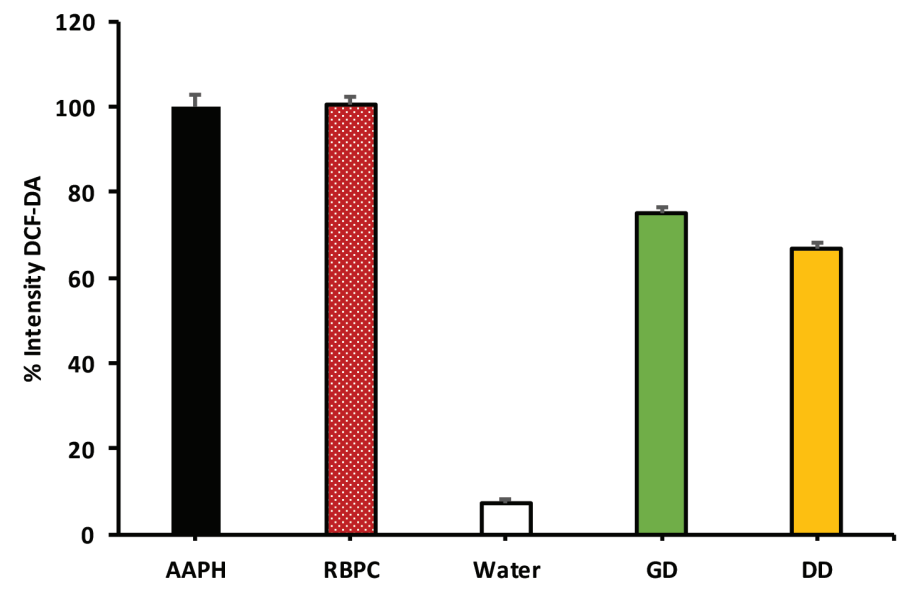

Figure 10. \% of intensity by DFC-DA fluorescence in presence of AAPH. AAPH (positive control), water (basal control without AAPH), DG (gastric digest incubated with AAPH), DD (duodenal digest incubated with AAPH) and RBPC (red bean protein concentrate incubated with AAPH). Results were analyzed using one-way ANOVA and followed by Tuckey's test. Different letter represents significant differences between sample as $p<0.05(n=5)$.result.

group of embryos treated with water present $7.0 \%$ of intensity of fluorescence when compared to the group of embryos treated with AAPH reactive.

\section{CONCLUSION}

Results obtained in this study demonstrate that RBPCs and RBPCs hydrolysates produced with in vitro gastrointestinal digestion model present antioxidant activity and inhibition of TBARs using the in vitro and in vivo zebrafish larvae model. RBPCs and their hydrolysates were able of inhibiting ROS formation in zebrafish embryos. RBPCs and their hydrolysates, due to their antioxidant capacity and their protein content, can be used in the food industry as functional ingredients. Other studies can be used to identify the sequences of antioxidant peptides and study their mechanisms of action. Moreover, a study is needed to determine their technological properties, such as protein solubility, water absorption capacity, oil absorption capacity, the emulsifying activity index, and finally determine their possible use in the food industry.

\section{ACKNOWLEDGMENTS}

This work was part of Project number CPU-1373-2014 of Universidad Técnica de Ambato (Ecuador), Universidad Nacional de Rio Negro (Argentina), Universidad Técnica de Babahoyo (Ecuador), Universidad Estatal de Bolívar (Ecuador), and Instituto Nacional de Investigaciones Agropecuarias, Departamento de Nutrición y Calidad (Ecuador).

\section{CONFLICT OF INTEREST}

The authors declare that they have no conflict of interest.

\section{REFERENCES}

Achouri A, Boye JI. Thermal processing, salt and high-pressure treatment effects on molecular structure and antigenicity of sesame protein isolate. Food Res Int, 2013; 53:240-51.

Achouri A, Nail V, Boye JI. Sesame protein isolate: Fractionation, secondary structure and functional properties. Food Res Int, 2012; 46:360-9.
Acosta C, Carpio C, Vilcacundo R, Carrillo W. Identification of proteins isolate from amaranth (Amaranthus caudatus) by sodium dodecyl sulfate-polyacrylamide gel electrophoresis with water and $\mathrm{NaCl} 0.1 \mathrm{~m}$ solvents. Asian J Pharm Clin Res, 2016; 9:331-.3

Adler-Nissen J. Determination of the degree of hydrolysis of food protein hydrolysates by trinitrobenzenesulfonic acid. J Agric Food Chem, 1979; 27:1256-62.

Akıllığlu HG, Karakay, S. Effects of heat treatment and in vitro digestion on the angiotensin converting enzyme inhibitory activity of some legume species. Eur Food Res Technol, 2009; 229:915-21.

AOAC. Official methods of analysis. Association Official Analytical Chemists, Washington, DC, 2012.

Arnao MB, Cano A, Acosta M. The hydrophilic and lipophilic contribution to total antioxidant activity. Food Chem, 2001; 73:239-44.

Barden L, Decker EA. Lipid oxidation in low-moisture food: a review. Crit Rev Food Sci Nutr, 2016; 56:2467-82.

Benzie IFF, Strain JJ. The ferric reducing ability of plasma (FRAP) as a measure of "antioxidant power": the FRAP assay. Ann Biochem, 1996; 239:70-6.

Boschin G, Scigliuolo GM, Resta D, Arnoldi A. ACE-inhibitory activity of enzymatic protein hydrolysates from lupin and other legumes. Food Chem, 2014; 145:34-40.

Boye J, Zare F, Pletch A. Pulse proteins: processing, characterization, functional properties and applications in food and feed. Food Res Int, 2010; 43:414-31.

Boye JI, Aksay S, Roufik S, Ribereau S, Mondor M, Farnworth E, Rajamohamed SH. Comparison of the functional properties of pea, chickpea and lentil protein concentrates processed using ultrafiltration and isoelectric precipitation techniques. Food Res Int, 2016; 43: 537-46.

Brand-Williams W, Cuvelier ME, Berset CLWT. Use of a free radical method to evaluate antioxidant activity. LWT-Food Sci Technol, $1995 ; 28: 25-30$.

Carbonaro M, Maselli P, Nucara A. Structural aspects of legume proteins and nutraceutical properties. Food Res Int, 2015; 76:19-30.

Cárdenas M, Carpio C, Welbaum J, Vilcacundo E, Carrillo W. Chia protein concentrate (Salvia hispanica L.) anti-inflammatory and antioxidant activity. Asian J Pharm Clin Res, 2018; 11:382-6.

Carrasco-Castilla J, Hernández-Álvarez AJ, Jiménez-Martínez C, Jacinto-Hernández C, Alaiz M, Girón-Calle J, Vioque J, Dávila-Ortiz G. Antioxidant and metal chelating activities of Phaseolus vulgaris L. var. Jamapa protein isolates, phaseolin and lectin hydrolysates. Food Chem, 2012; 131:1157-116.

Carrillo W, Barrio D, Welbaum J, Carpio C, Vilcacundo R, Morales D, Ortiz J. Antimicrobial and antioxidant peptides obtained from food proteins. In: Powell K (ed.). Bioactive peptides: types, roles and research, Nova Science Publisher, New York, NY, pp 37-58, 2017a; ISBN 978-1-53610-994-8.

Carrillo W, Gómez-Ruiz JA, Miralles B, Ramos M, Barrio D, Recio I. Identification of antioxidants peptides of hen egg white lysozyme and evaluation of inhibition of lipid peroxidation and cytotoxicity in the zebrafish model. Eur Food Res Technol, 2016a; 242:1777-85.

Carrillo W, Guzmán X, Vilcacundo E. Native and heated hydrolysates of milk proteins and their capacity to inhibit lipid peroxidation in the zebrafish larvae model. Foods, 2017b; 6:81.

Carrillo W, Tubón J, Vilcacundo R. Isolation of hen egg White lysozyme by cation Exchange chromatography, analysis of its digestibility and evaluation of the inhibition lipid peroxidation in zebrafish model. Asian J Pharm Clin Res, 2016b; 9:345-9.

Cunliffe VT. Zebrafish: a practical approach. In: NüssleinVolhard C, Dahm R (eds.). Genet Res, vol. 82, Oxford University Press, Oxford, UK, pp 79-83, 2003.

Das MP, Suguna PR, Prasad K, JV V, MR. Extraction and characterization of gelatin: a functional biopolymer. Int J Pharm Pharm Sci, 2017; 9:239-42. 
De la Caba K, Pena C, Ciannamea EM, Stefani PM, Mondragon I, Ruseckaite RA. Characterization of soybean protein concentrate-stearic acid/ palmitic acid blend edible films. J Appl Polymer Sci, 2012; 124:1796-807.

Felsted RL, Li J, Pokrywka G, Egorin MJ, Spiegel J, Dale RM. Comparison of Phaseolus vulgaris cultivars on the basis of isolectin differences. Int J Biochem, 1981; 13:549-57.

Foschia M, Horstmann SW, Arendt EK, Zannini E. Legumes as functional ingredients in gluten-free bakery and pasta products. Ann Rev Food Sci Technol, 2017; 8:75-96.

Galadari S, Rahman A, Pallichankandy S, Thayyullathil F. Reactive oxygen species and cancer paradox: to promote or to suppress? Free Rad Biol Med, 2017; 104:144-64.

García-Mora P, Frías J, Peñas E, Zieliński H, Giménez-Bastida JA, Wiczkowski W, Zielnska D, Martínez-Villaluenga C. Simultaneous release of peptides and phenolics with antioxidant, ACE-inhibitory and antiinflammatory activities from pinto bean (Phaseolus vulgaris L. var. pinto) proteins by subtilisin. J Funct Foods, 2015; 18:319-32.

Goh AR, Youn GS, Yoo KY, Won MH, Han SZ, Lim SS, Lee KW, Choi SY, Park J. Aronia melanocarpa concentrate ameliorates pro-inflammatory responses in $\mathrm{HaCaT}$ keratinocytes and 12-O-tetradecanoylphorbol-13-acetate-induced ear edema in mice. J Med Food, 2016; 19:654-62.

Hall TC, Chandrasekharan MB, Li G. Phaseolin: its past, properties, regulation and future. In: Shewry PR, Casey R (eds.). Seed proteins, Kluwer Academic Publishers, Dordrecht, The Netherlands, pp 209-40, 1999.

Hue C, Gunata Z, Bergounhou A, Assemat S, Boulanger R, Sauvage FX, Davrieux F. Near infrared spectroscopy as a new tool to determine cocoa fermentation levels through ammonia nitrogen quantification. Food Chem, 2014; 148:240-5.

Jensen GS, Attridge VL, Beaman JL, Guthrie J, Ehmann A, Benson KF. Antioxidant and anti-inflammatory properties of an aqueous cyanophyta extract derived from arthrospira platensis: contribution to bioactivities by the non-phycocyanin aqueous fraction. J Med Food, 2015; 18:535-41.

Kang MC, Kim SY, Kim YT, Kim EA, Lee SH, Ko SC, Jang HS. In vitro and in vivo antioxidant activities of polysaccharide purified from aloe vera (Aloe barbadensis) gel. Carbohyd Polymers, 2014; 99:365-71.

Lara D, Vilcacundo E, Carrillo C, Carpio C, Silva M, Alvarez $\mathrm{M}$, Carrillo W. Obtention of protein concentrate and polyphenols from macadamia (Macadamia integrifolia) with aqueous extraction method. Asian J Pharm Clin Res, 2017; 10:303-6.

Lee SH, Ko CI, Jee Y, Jeong Y, Kim M, Kim JS, Jeon YJ. Antiinflammatory effect of fucoidan extracted from Ecklonia cava in zebrafish model. Carbohyd Polymers, 2013; 92:84-9.

Lin PY, Lai HM. Bioactive compounds in legumes and their germinated products. J Agric Food Chem, 2006; 54:3807-14.

Liu H, Wang B, Barrow CJ, Adhikari B. Relating the variation of secondary structure of gelatin at fish oil-water interface to adsorption kinetics, dynamic interfacial tension and emulsion stability. Food Chem, 2014; 143:484-91.

Lopez-Pedrouso M, Bernal J, Franco D, Zapata C. Evaluating two-dimensional electrophoresis profiles of the protein phaseolin as markers of genetic differentiation and seed protein quality in common bean (Phaseolus vulgaris L.). J Agric Food Chem, 2014; 62:7200-8.

Luján-Facundo MJ, Mendoza-Roca JA, Cuartas-Uribe B, Álvarez-Blanco S. Evaluation of cleaning efficiency of ultrafiltration membranes fouled by BSA using FTIR-ATR as a tool. J Food Eng, 2015; $163: 1-8$.

Luna-Vital DA, Mojica L, de Mejía EG, Mendoza S, Loarca-Piña G. Biological potential of protein hydrolysates and peptides from common bean (Phaseolus vulgaris L.): a review. Food Res Int, 2015; 76:39-50.

Mamilla RK, Mishra VK. Effect of germination on antioxidant and ACE inhibitory activities of legumes. LWT-Food Sci Technol, 2017; 75:51-8.
Minekus $\mathrm{M}$, Alminger $\mathrm{M}$, Alvito $\mathrm{P}$, Ballance $\mathrm{S}$, Bohn $\mathrm{T}$, Bourlieu C, Carrière F, Boutrou R, Corredig M, Dupont D, Dufour C, Egger L, Golding M, Karakaya S, Kirkhus B, Le Feunteun S, Lesmes U, Macierzanka A, Mackie A, Marze S, McClements DJ, Ménard O, Recio I, Santos CN, Singh RP, Vegarud GE, Wickham MS, Weitschies W, Brodkorb A. A standardized static in vitro digestion method suitable for food-an international consensus. Food Funct, 2014; 5: 1113-1124.

Montoya CA, Lallès JP, Beebe S, Leterme P. Phaseolin diversity as a possible strategy to improve the nutritional value of common beans (Phaseolus vulgaris). Food Res Int, 2010; 43:443-9.

Montoya CA, Leterme P, Victoria NF, Toro O, Souffrant WB, Beebe S, Lallès JP. Susceptibility of phaseolin to in vitro proteolysis is highly variable across common bean varieties (Phaseolus vulgaris). J Agric Food Chem, 2008; 56:2183-91.

Navarro-Lisboa R, Herrera C, Zúñiga RN, Enrione J, Guzmán F, Matiacevich S, Astudillo-Castro C. Quinoa proteins (Chenopodium quinoa Willd.) fractionated by ultrafiltration using ceramic membranes: the role of $\mathrm{pH}$ on physicochemical and conformational properties. Food Bioprod Process, 2017; 102:20-30.

Ou B, Huang D, Hampsch-Woodill M, Flanagan JA, Deemer EK Analysis of antioxidant activities of common vegetables employing oxygen radical absorbance capacity (ORAC) and ferric reducing antioxidant power (FRAP) assays: a comparative study. J Agric Food Chem, 2002; 50:3122-8.

Pazmiño A, Vásquez G, Carrillo W. Pigeon pea protein concentrate (Cajanus cajan) seeds grown in Ecuador functional properties. Asian J Pharm Clin Res, 2018; 11:430-5.

Poveda T, Vilcacundo R, Carpio C, Carrillo W. Analysis of sesame proteins isolate (Sesamum indicum $\mathrm{L}$ ) with water and salt treatment. Asian J Pharm Clin Res, 2016; 9:404-7.

Quinteros MF, Vilcacunco R, Carpio C, Carrillo W. Isolation of proteins from sacha inchi (Plukenetia volubilis L.) in presence of water and salt. Asian J Pharm Clin Res, 2016; 9:193-6.

Rodríguez Saint-Jean S, las Heras A, Carrillo W, Recio I, OrtizDelgado JB, Ramos M, Pérez-Prieto SI. Antiviral activity of casein and s2 casein hydrolysates against the infectious hematopoietic necrosis virus, a rhabdovirus from salmonid fish. J Fish Dis, 2013; 36:467-81.

Rosenkranz AR, Schmaldienst S, Stuhlmeier KM, Chen W, Knapp W, Zlabinger GJ. A microplate assay for the detection of oxidative product using 2\%,7\%-dichlorofluorescein-diacetate. J Immunol Methods, $1992 ; 156: 39-45$.

Serrano S, Rincón F, García-Olmo J. Cereal protein analysis via Dumas method: standardization of a micro-method using the Euro Vector Elemental Analyzer. J Cereal Sci, 2013; 58:31-6.

Singleton VL, Rossi JA. Colorimetry of total phenolics with phosphomolybdic-phosphotungstic acid reagents. Am J Enol Vitic, 1965; 16:144-58.

Sprague J, Bayraktaroglu L, Clements D, Conlin T, Fashena D, Frazer K, Haendel M, Howe DG, Mani P, Ramachandran S, Schaper K, Segerdell E, Song P, Sprunger B, Taylor S, Van Slyke CE, Westerfield M. The zebrafish information network: the zebrafish model organism database. Nuc Acids Res, 2006; 34:D581-5.

Toapanta A, Carpio C, Vilcacundo R, Carrillo W. Analysis of protein isolate from quinoa (Chenopodium quinoa Willd). Asian J Pharm Clin Res, 2016; 9:332-4.

Torres J, Rutherfurd SM, Muñoz LS, Peters M, Montoya CA. The impact of heating and soaking on the in vitro enzymatic hydrolysis of protein varies in different species of tropical legumes. Food Chem, 2016; 194:377-82.

Torruco-Uco J, Chel-Guerrero L, Martínez-Ayala A, DávilaOrtíz G, Betancur-Ancona D. Angiotensin-I converting enzyme inhibitory and antioxidant activities of protein hydrolysates from Phaseolus lunatus and Phaseolus vulgaris seeds. LWT-Food Sci Technol, 2009; 42:1597-604.

Tosh SM, Yada S. Dietary fibres in pulse seeds and fractions: characterization, functional attributes, and applications. Food Res Int, 2010; 43:450-60. 
Valdez-Ortiz, A, Fuentes-Gutiérrez CI, Germán-Báez LJ, Gutiérrez-Dorado R, Medina-Godoy S. Protein hydrolysates obtained from Azufrado (sulphur yellow) beans (Phaseolus vulgaris): nutritional, ACEinhibitory and antioxidative characterization. LWT-Food Sci Technol, 2012; 46:91-6.

Vilcacundo R, Barrio D, Carpio C, García-Ruiz A, Rúales J, Hernández-Ledesma B, Carrillo W. Digestibility of quinoa (Chenopodium quinoa Willd.) protein concentrate and its potential to inhibit lipid peroxidation in the Zebrafish larvae model. Plant Foods Hum Nutr, 2017; 72:294-300.

Vilcacundo R, Barrio DA, Piñuel L, Boeri P, Tombari A, Pinto A, Welbaum J, Hernández-Ledesma B, Carrillo W. Inhibition of Lipid Peroxidation of Kiwicha (Amaranthus caudatus) Hydrolyzed protein using zebrafish larvae and embryos. Plants, 2018a; 7:69.

Vilcacundo R, Miralles B, Carrillo W, Hernández-Ledesma B. In vitro chemopreventive properties of peptides released from quinoa (Chenopodium quinoa Willd.) protein under simulated gastrointestinal digestion. Food Res Int, 2018b; 105:403-11.
Zhao K, Zhao GM, Wu D, Soong Y, Birk AV, Schiller PW, Szeto HH. Cell-permeable peptide antioxidants targeted to inner mitochondrial membrane inhibit mitochondrial swelling, oxidative cell death, and reperfusion injury. J Biol Chem, 2004; 279:34682-90.

Zhao X, Chen F, Xue W, Lee L. FTIR spectra studies on the secondary structures of $7 \mathrm{~S}$ and $11 \mathrm{~S}$ globulins from soybean proteins using AOT reverse micellar extraction. Food Hydrocoll, 2008; 22:568-75.

How to cite this article:

Piñuel L, Vilcacundo E, Boeri P, Barrio DA, Morales D, Pinto A, Moran R, Samaniego I, Carrillo W. Extraction of protein concentrate from red bean (Phaseolus vulgaris L.): antioxidant activity and inhibition of lipid peroxidation. $\mathrm{J}$ Appl Pharm Sci, 2019; 9(09):045-058. 